\title{
From Scatter to Mound: A New Developmental Model for Shell Mound Sites at Weipa
}

\author{
Mick Morrison \\ Department of Archaeology, Flinders University, GPO Box 2100, Adelaide SA 5001, Australia \\ Mick.Morrison@flinders.edu.au
}

\begin{abstract}
Recent research on shell mounds near Weipa (northeast Australia) has focussed on economic questions, particularly understanding what these sites reveal about the production strategies of Aboriginal people and possible links to broader social and environmental transformations documented in late Holocene northeastern Australia. However, in order to explore such issues it is necessary to acquire a firm understanding of mound development through reference to detailed stratigraphic, chronological and compositional data. This paper presents results of investigations into the developmental history of a range of shell matrix sites including shell scatters, non-mounded middens and mounds that occur at Bweening, to the north of Weipa. It is argued that the early stages of mound formation involved multiple small-scale (1-2m diameter) discard events in 'clusters' within close proximity to one another, coalescing through time to form low dome-shaped mounds. However, site development is characterised by a high degree of spatial variability in terms of where discard activities were focussed, and appears to shift in response to quite localised factors.
\end{abstract}

\section{Introduction}

Shell mounds near Weipa, western Cape York Peninsula, remain an enigmatic part of coastal landscapes in this region and despite sporadic archaeological work over 40 years, basic questions about their origins and role in past Aboriginal societies remain to be addressed. This is partly due to the paucity of published data for the region, and until recently, detailed compositional data was only available for several sites. Recent work has illustrated considerable variability in terms of shell matrix sites in the region, with a minimum of 523 sites recorded to date including scatters, non-mounded middens and mounds across a range of environmental contexts around Albatross Bay and its estuaries (Morrison 2013). As such, shell matrix sites provide important opportunities for researchers investigating the characteristics of late Holocene Aboriginal economies and recent work has focussed upon investigating the production strategies associated with mound formation and possible links between the appearance of these sites after approximately 2500 cal BP and social, demographic and environmental changes documented in other parts of northeastern Australia at this time (Haberle and David 2004; McNiven et al. 2006).

The recently proposed 'niche production model' (Morrison 2013) asserts that mound use was characterised by a high degree of flexibility in terms of resource focus, at times involving a considerable emphasis on the intertidal bivalve Anadara granosa, but also incorporating other estuarine resources, and that the level or intensity of production was able to be scaled up or down in line with resource availability and abundance. This production system was based upon nuanced knowledge of annual and intra-annual ecosystem dynamics along with social organisation and communication networks that facilitated a high degree of flexibility around the strategic exploitation of variable estuarine resource bases. Further development and evaluation of this or other models is of course entirely dependent upon new data, particularly data on mound composition and chronology that is of sufficient resolution to explore relatively fine-scaled local developmental histories of not only individual sites, but entire suites of sites within specific geographic locales (see also Bailey 1999; Morrison 2003, 2013).

Studies of the development of shell mound sites at Weipa are typically complicated by the presence of naturally occurring shell within the Holocene coastal sediments on which mounds occur. This can cause some difficulty in disentangling natural and cultural processes associated with mound formation - a somewhat notorious issue in the region (e.g. Bailey 1977; Bailey et al. 1994; Stanner 1961; Stone 1989, 1995; Valentin 1959; Wright 1971). An important but unacknowledged limitation in previous archaeological work on mound sites near Weipa is that previous investigations have used samples exclusively obtained from sites on landforms influenced by coastal processes, such as beach ridges and coastal plains (e.g. Bailey 1977; Bailey et al. 1994; Stone 1995). This complicates the task of unravelling processes of site formation because it is impossible to rule out at least some influence from major natural processes such as storm surges in the formation of mound sites on such substrates. Here, new data resulting from the investigations of a suite of nine shell matrix sites at Bweening, on the Mission River to the immediate north of Weipa are presented. This study area was selected because it is an elevated coastal escarpment $3-5 \mathrm{~m}$ above current sea-level and as such is unlikely to have undergone any deposition of coastal sediments during the Holocene, allowing for a more focussed consideration of mound development processes. These sites were excavated in order to understand local variations in mound stratigraphy, chronology and composition across an approximately $3 \mathrm{~km}$ stretch of coastline via an investigation of both mounded and non-mounded shell matrix sites in this area in order to develop a new model for the early stages of shell mound formation.

\section{The Study Area}

Bweening is on the northern side of the Mission River to the north of Weipa (Figure 1). The dominant landforms in the region are Cainozoic ferruginous duricrust plateaus (Taylor and Eggleton 2004; Taylor et al. 2008) that are locally known as 'bauxite plateaus' due to the widespread 


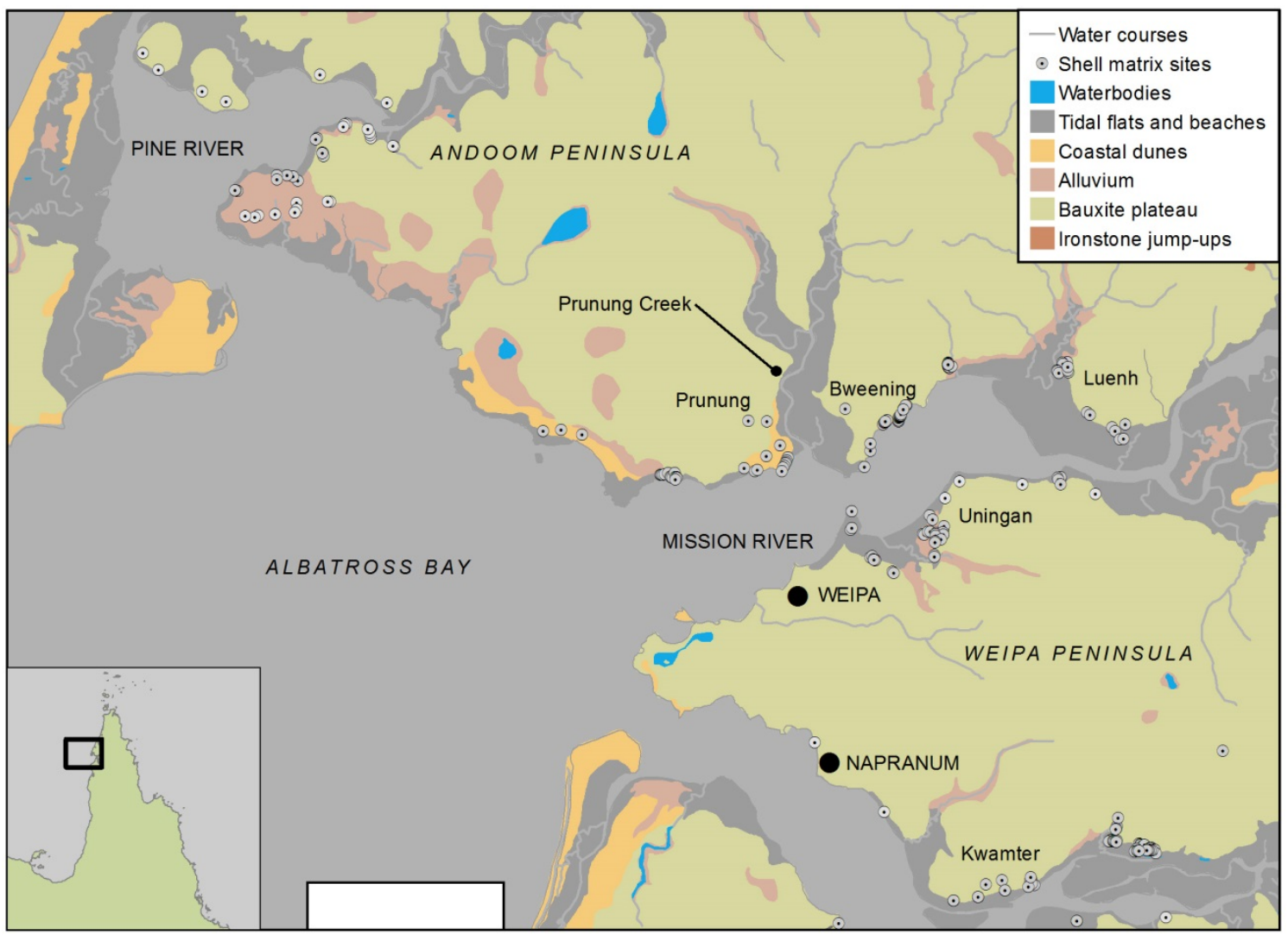

Figure 1. Landforms and shell matrix site locations on the north Mission River, Weipa.

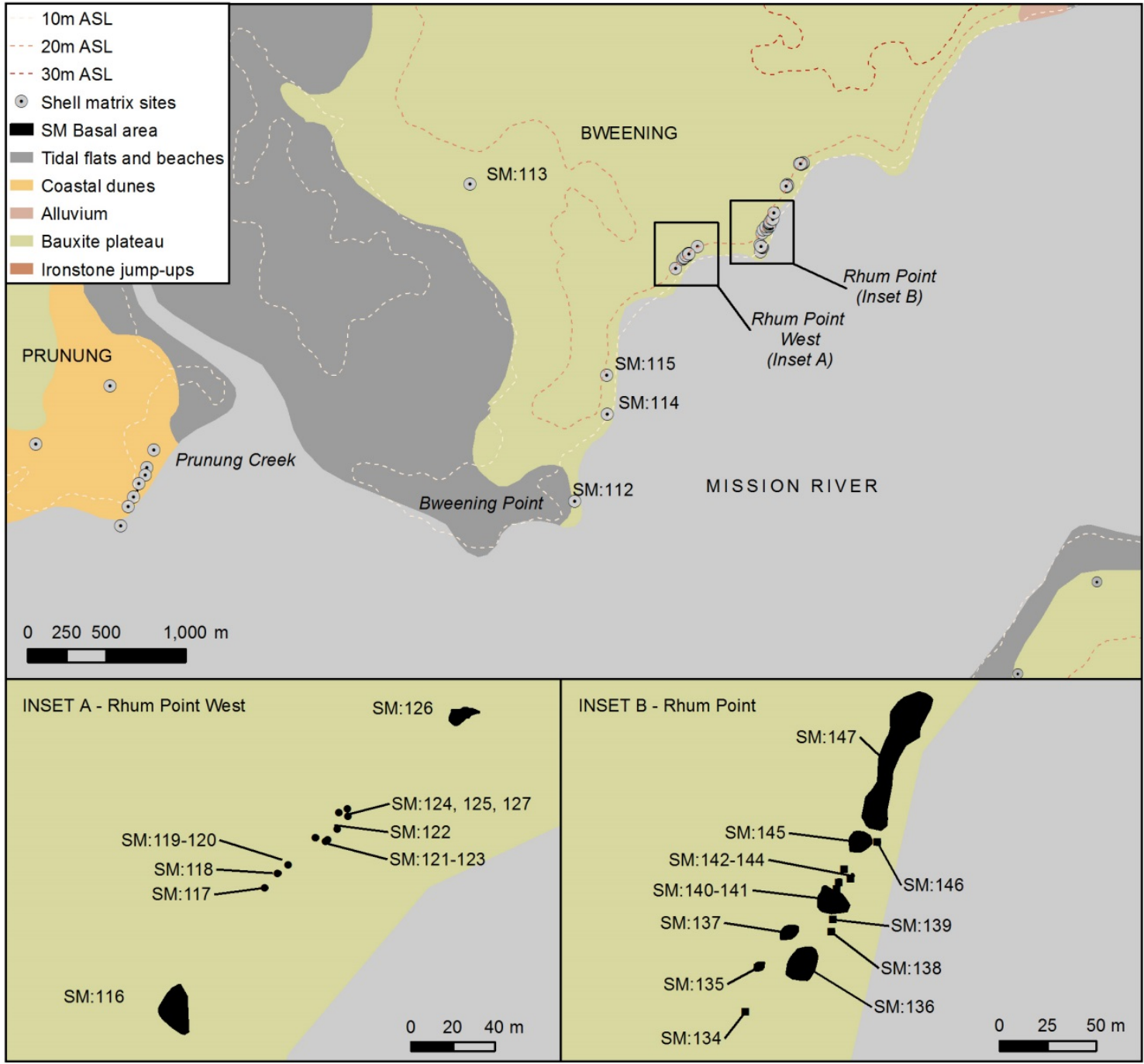

Figure 2. Archaeological sites at Bweening. 
occurrence of this mineral within these deposits. The plateau at Bweening is characteristic of others that occur in the region and is composed of a $2-3 \mathrm{~m}$ deep layer of pisolitic bauxite beneath a shallow soil profile (Eggleton and Taylor 2008; Taylor and Eggleton 2004; Taylor et al. 2008). The plateau ends abruptly at the Mission River forming a more-or-less continuous $3-5 \mathrm{~m}$ sheer escarpment for several kilometres of coastline with exposed rocky headlands alternated by small bays with narrow sandy beaches and intertidal mudflats extending several hundred metres from the shoreline. Significantly, the escarpment edge is above the height of any Holocene coastal influence and lacks any marine deposits such as cheniers or beach ridges. The only exception to this is near Prunung Creek where the eroded plateau margin transitions to a low-lying marine plain (Figure 2).

The bauxite plateau is incised by Prunung Creek to the west and a small unnamed creek to the east (Figure 2). The vegetation on the plateau consists of a tall $(20-30 \mathrm{~m})$ stratum of Eucalyptus tetrodonta woodland (Godwin 1985; Specht et al. 1977), however, other more restricted landforms and ecosystems also occur in settings where either erosion or aggradation of the plateau has occurred, such as near stream channels or at the coastal margin. These include mangrove dominant ecosystems and restricted areas of Melaleuca spp. forest near Prunung Creek as well as occasional isolated stands of dry notophyll vine forest on the plateau itself (Figure 2).

Previous archaeological work in the Weipa region is well summarised elsewhere (Bailey 1993, 1999; Bailey et al. 1994; Morrison 2013), however, key sites include Kwamter which was the focus of initial excavations in the region (Bailey 1977; Wright 1971), as well as Prunung to the west where geoarchaeological work was undertaken in the 1990s (Bailey et al. 1994) (Figure 1). Extensive surveys in the region provide a detailed picture of the distribution of shell matrix sites around Albatross Bay (Bailey 1977, 1994; Morrison 2013) and locations of all known sites within the Mission River area are shown in Figure 1.

Most work on the Mission River has taken place at Prunung, to the immediate west of Bweening (Figure 2). Beaton conducted some sampling here and these results are summarised within the context of later work by Bailey et al. (1994). Stone (1995) dated and analysed a sequence of shore-parallel beach ridges at Prunung and interpreted all of the shell mound deposits here as having been naturally formed via ornithogenesis (Stone 1995). However, more recent work demonstrated the artificial nature of these deposits compared with underlying and adjacent sand-dominant natural substrates supporting the argument that these mounds are cultural (Bailey 1993; Bailey et al. 1994; Morrison 2010).

The largest concentration of shell matrix sites at Bweening is at Rhum Point where 14 discrete sites have been recorded (Figure 2). The largest of these is SM:147, a shell mound $75 \mathrm{~m}$-long, $15 \mathrm{~m}$-wide and up to $1.5 \mathrm{~m}$-high, and that is presumably the same site sampled by Beaton though four smaller $(<0.5 \mathrm{~m}$-high) mounds (SM:140, SM:136, SM:145 and SM:137) and other discrete scatters of A. granosa 1-2m in diameter also occur here. A second concentration of shell matrix sites occurs at Rhum Point West, approximately $500 \mathrm{~m}$ to the west of Rhum Point behind a dense stand of dry notophyll vine forest and include three low mounds or middens (SM116, SM:117 and SM:126) and a series of discrete but low density shell scatters (SM:117-125, SM:127). The final two features in the Bweening study area were small shell mounds SM:114 and SM:115 both of which are relatively isolated from the Rhum Point and Rhum Point West groups of sites.

Beaton obtained a basal radiocarbon determination on a $1.4 \mathrm{~m}$-high shell mound site at Bweening, which returned an uncorrected date of $970 \pm 60 \mathrm{BP}$ (ANU-4421) (Stone 1995:83), however, as with other work by Beaton in this area, no contextual information on the sample is available. Beaton also obtained dates for larger mound clusters at Luenh to the east (see Stone 1995), as well as on one large mound site at Prunung (see Bailey et al. 1994).

\section{Methods}

Excavations were undertaken as part of a cultural heritage management project investigating damage to a number of sites in the study area (Morrison 2002). Consequently, the excavations were partly mitigative in focus and involved the comparative analysis of samples of disturbed deposits alongside samples obtained through controlled excavation of undisturbed sites. Excavations and analysis took place in 2002-2003.

\section{Excavations}

Excavation involved the controlled removal of $50 \mathrm{~cm}^{2}$ to $1 \mathrm{~m}^{2}$ column samples from a range of sites via arbitrary $3-$ $5 \mathrm{~cm}$ spits before being placed through $6 \mathrm{~mm}$ and $2 \mathrm{~mm}$ nested sieves. The $6 \mathrm{~mm}$ residues contained many kilograms of whole shellfish and shellfish fragments of a range of sizes, typically dominated by A. granosa. Thankawith traditional owners stipulated that large amounts of cultural material should not be removed from the region and so two sampling strategies were developed and applied to reduce the amount of cultural materials to be removed:

Sampling Strategy A: This involved splitting the $6 \mathrm{~mm}$ sample into two subsamples, each of which were treated differently. The first, usually about $25-50 \%$ by weight of total $6 \mathrm{~mm}$ residues, were retained unsorted for detailed laboratory analysis. The second subsample (the remaining $6 \mathrm{~mm}$ residues) was hand-sorted to remove diagnostic $A$. granosa valves which were in turn weighed, counted and then used for backfill, a strategy similar to that reported by Robins et al. (1998). This created issues for quantifying the proportions of $A$. granosa in relation to other molluscan species, and this is discussed below. This strategy was used on all controlled excavations.

Sampling Strategy B: $6 \mathrm{~mm}$ residues were hand-sorted and all diagnostic $A$. granosa removed and quantified. A 20$25 \%$ subsample of the remaining residues, free of diagnostic A. granosa, was retained intact for laboratory analysis while the remaining $75-80 \%$ of $6 \mathrm{~mm}$ subsamples was hand sorted in the field for bone, artefacts and other uncommon materials and then returned to the site for backfilling. This sampling strategy was used exclusively on salvage work undertaken on cultural materials recovered via sieving of spoil heaps created by earthmoving equipment. 
The proportion of $2 \mathrm{~mm}$ sieve residues recovered varied between sites and even between different spits within a site. Where only small amounts were recovered all $2 \mathrm{~mm}$ residues were retained; however, in cases where large proportions of $2 \mathrm{~mm}$ residues were recovered only small samples (usually 25-50\%) were retained.

\section{Laboratory Methods}

After cleaning, the initial step in quantification was the separation of the bulk residues into the primary categories of shellfish remains, non-diagnostic shellfish remains (shell hash), stone/other artefacts, non-molluscan faunal materials, vegetative materials and unmodified stones. Shellfish analysis methods are discussed below. All 6mm residues transported to the laboratory were sorted and quantified. A strategic approach was taken to the investigation of $2 \mathrm{~mm}$ residues and focussed upon the excavation units in each pit with the greatest proportion of non-molluscan fauna recovered in $6 \mathrm{~mm}$ residues.

Analysis of $2 \mathrm{~mm}$ materials was specifically focussed on the identification of non-molluscan faunal remains, stone artefacts and diagnostic shellfish elements. Nondiagnostic shell, bauxite pisoliths or other materials in the fine sieve fraction subsample were not quantified.

\section{Shellfish Analysis}

Shellfish remains were sorted by genus or species. Nondiagnostic shellfish were not sorted by species because a more accurate picture of shellfish representation could be obtained by targeting diagnostic elements, regardless of their size. Unambiguous criteria for identifying diagnostic specimens were used consistently throughout the shellfish analysis (Table 1).

Both weights and the Minimum Number of Individuals (MNI) of diagnostic shellfish elements were recorded for each excavation unit. Quantifying via weight was found to lead to the over-representation of species with denser shell or greater weights, and the underrepresentation of lighter species. Marcia hiantina is a typical example. This species was often highly fragmented and diagnostic elements (in this case, complete hinges) were often $5-10 \mathrm{~mm}$ in length and only a few grams in weight; therefore abundance estimates based on weight of these elements alone would be highly problematic if compared with more robust species such as A. granosa or Saccostrea cucullata. Mowat (1994) also noted this problem and recommended MNI for shellfish quantification. Here, MNI data are reported and drawn upon for interpretive purposes.

The field sampling procedures involving the removal of A. granosa had significant implications when it came to quantifying shellfish composition. For Sampling Strategy A, the MNI of the discarded A. granosa was estimated by calculating a mean valve weight for diagnostic A. granosa valves in the subsample retained for detailed laboratory analysis. This mean valve weight estimate was then used to calculate the number of valves discarded in the field, and from this an MNI estimate was calculated. Sampling Strategy B posed different problems because all $A$. granosa were quantified in the field (weights and MNI) before being used as backfill, with a $20-25 \%$ subsample of the remaining $6 \mathrm{~mm}$ residues retained for laboratory analysis. A. granosa weight and numbers were adjusted downwards to reflect the percentage of $6 \mathrm{~mm}$ residues sorted and quantified in detail. This effectively meant that shellfish quantification was based on a $20-25 \%$ subsample of the $6 \mathrm{~mm}$ residues remaining after the removal of diagnostic A. granosa in the field.

\section{Radiocarbon Dating}

Radiocarbon determinations on marine shellfish require correction for the marine reservoir effect (see Ulm 2002, 2006) and calibration curves are applicable to those of late Holocene age because uncorrected conventional radiocarbon ages strongly influence subsequent interpretations. Here, all conventional radiocarbon ages have been calibrated with CALIB version 6.10 (Stuiver and Reimer 1993) using data from the Marine09 calibration curve (Reimer et al. 2009). Ulm (2006) has calculated a subregional Gulf of Carpentaria average of $55 \pm 98 \mathrm{BP}$ by disregarding the $\Delta \mathrm{R}$ values of shell samples from the Torres Strait. However, more recent work in the eastern Gulf of Carpentaria (Ulm et al. in press) has produced a new $\Delta \mathrm{R}$ value of $-103 \pm 1614 \mathrm{C}$ years for the northwest coast of Cape York Peninsula BP that has been used here.

\section{Results}

A total of nine sites at Bweening were sampled during the investigation and these included shell scatters, nonmounded middens and mounds. This allowed for a finegrained picture of patterns of the stratigraphy, chronology and composition to be established for the study area while also permitting different sites types to be investigated and possible formation processes to be explored.

\section{SM:137}

SM:137 is a discrete shell matrix site which forms part of the cluster of sites that occur a few hundred metres to the north of Rhum Point (Figure 2). The site had been extensively damaged as a result of earth-moving equipment removing the upper deposits and was estimated to be $6 \mathrm{~m} \times 9 \mathrm{~m}$ in basal area and less than $30 \mathrm{~cm}$ in height prior to this disturbance. A shallow $0.5 \mathrm{~m}^{2}$ test pit (SM:137a) was excavated on the least disturbed part of the site to a total depth of $27 \mathrm{~cm}$ below surface (BS). The upper layer consisted of loosely-packed whole and fragmented marine shell in a matrix of fine brown soil above a natural substrate consisting of ironstone nodules and bauxite pisoliths in fine compact reddish soil. The proportions of diagnostic shellfish were highest in XUs 1 and 2 and decreased significantly in XUs 3 and 4 (Table 2). This decrease in shellfish proportions was accompanied by increased proportions of bauxite pisoliths and reddish soil and collectively represented the primary stratigraphic variation in the test pit. Because of the volume of disturbed deposit present in spoil heaps adjacent to the site, sieving of samples of these sediments was undertaken in order to recover information about the site's composition and are referred to here as SM:137sh.

A single sample of A. granosa shell was subjected to radiocarbon dating from the interface between the substrate and the lowest undisturbed shell deposits on SM:137a. No sample of the upper age of this site was possible owing to removal of the upper deposits. Data on shellfish composition were obtained from the spoil heaps of midden material adjacent to the site and these are seen 
Table 1. Shellfish diagnostic criterion.

\begin{tabular}{|l|l|l|}
\hline \multicolumn{1}{|c|}{ Type } & \multicolumn{1}{|c|}{ Diagnostic Criterion } & \multicolumn{1}{c|}{ MNI Calculations } \\
\hline Symmetrical bivalves & $\begin{array}{l}\text { Complete hinge including cardinal teeth, lateral } \\
\text { teeth and umbo. Completeness of valve not } \\
\text { necessary. }\end{array}$ & $\begin{array}{l}\text { Total diagnostic valves } \\
\text { divided by two }\end{array}$ \\
\hline Asymmetrical bivalves & $\begin{array}{l}\text { For rock oysters (S. cucullata): the presence of } \\
\text { a complete hinge on the base or a full adductor } \\
\text { scar on the lid (top). }\end{array}$ & $\begin{array}{l}\text { Sum of the most frequent } \\
\text { element (i.e. bases or lids) }\end{array}$ \\
\hline Gastropods - Globular shape & $\begin{array}{l}\text { Fragment consisting of intact inductura, } \\
\text { umbilicus and umbilical callus. }\end{array}$ & Sum of diagnostic elements \\
\hline Gastropods - Conic shape & $\begin{array}{l}\text { Fragment consisting of a complete spire, } \\
\text { specifically the presence of nuclear whorls. }\end{array}$ & Sum of diagnostic elements \\
\hline
\end{tabular}

Table 2. SM:137 excavation data.

\begin{tabular}{|l|r|r|r|r|}
\hline & \multicolumn{1}{|c|}{ XU1 } & \multicolumn{1}{c|}{ XU2 } & \multicolumn{1}{c|}{ XU3 } & \multicolumn{1}{c|}{ XU4 } \\
\hline Unit depth $(\mathrm{cm})$ & 5.7 & 5.7 & 8.5 & 6.9 \\
\hline Gross weight $(\mathrm{g})$ & 17500 & 21000 & 20500 & 6500 \\
\hline 6mm residue $(\mathrm{g})$ & 3300 & 3468 & 1099 & 407 \\
\hline 2mm residue $(\mathrm{g})$ & 2410 & 2885 & 4871 & 1568 \\
\hline Soil $(\mathrm{g})$ & 11790 & 14647 & 14530 & 4525 \\
\hline Stones $(\mathrm{g})$ & 633 & 594 & 840 & 385 \\
\hline Charcoal $(\mathrm{g})$ & 1 & 2 & - & - \\
\hline Non-diagnostic shell $(\mathrm{g})$ & 1817 & 1776 & 152 & 23 \\
\hline Diagnostic shell $(\mathrm{g})$ & 827 & 1073 & 101 & 6 \\
\hline
\end{tabular}

Table 3. Radiocarbon determinations, Bweening. Note that ANU-4421 was collected by Beaton, and the likely source was SM:147; however, no contextual data are available (see Bailey et al. 1994).

\begin{tabular}{|c|c|c|c|c|c|c|}
\hline Lab. No. & $\begin{array}{c}\text { Site } \\
\text { Number }\end{array}$ & $\begin{array}{c}\text { Depth } \\
(\mathbf{c m})\end{array}$ & Sample & $\begin{array}{c}\mathbf{\delta}^{\mathbf{1 3}} \mathbf{C} \\
\mathbf{( \% )}\end{array}$ & $\begin{array}{c}{ }^{14} \text { C Age } \\
\text { (years BP) }\end{array}$ & $\begin{array}{c}\text { Calibrated Age BP } \\
\mathbf{6 8 . 3 \%}\end{array}$ \\
\hline ANU-4421 & 147 & ${ }^{\text {Basal' }}$ & A. granosa & -1.1 & $970 \pm 60$ & $439(488) 534$ \\
\hline Wk-12155 & 137 & 20 & A. granosa & $-2.1 \pm 0.2$ & $1475 \pm 47$ & $858(918) 977$ \\
\hline Wk-12156 & 126 & 2 & A. granosa & $-2 \pm 0.2$ & $938 \pm 53$ & $423(464) 511$ \\
\hline Wk-12157 & 126 & 19 & A. granosa & $-2.3 \pm 0.2$ & $896 \pm 55$ & $376(427) 492$ \\
\hline Wk-12158 & $123 \mathrm{a}$ & 3.5 & A. granosa & $-1.9 \pm 0.2$ & $603 \pm 49$ & $1(125) 226$ \\
\hline Wk-12159 & $116 \mathrm{~b}$ & 25 & A. granosa & $-2 \pm 0.2$ & $820 \pm 60$ & $298(364) 421$ \\
\hline Wk-12160 & $115 \mathrm{a}$ & 4 & A. granosa & $-1.7 \pm 0.2$ & $740 \pm 61$ & $154(283) 395$ \\
\hline Wk-12161 & $114 \mathrm{c}$ & 17 & A. granosa & $-1.7 \pm 0.2$ & $816 \pm 47$ & $303(361) 410$ \\
\hline Wk-13786 & $140 \mathrm{a}$ & 20 & A. granosa & $-2.1 \pm 0.2$ & $917 \pm 41$ & $419(451) 495$ \\
\hline Wk-13784 & 147 & 130 & A. granosa & $-1.2 \pm 0.2$ & $1528 \pm 41$ & $920(973) 1018$ \\
\hline Wk-13785 & 136 & 25 & A. granosa & $-2.2 \pm 0.2$ & $715 \pm 41$ & $148(256) 305$ \\
\hline
\end{tabular}

Table 4. SM:137a shellfish composition.

\begin{tabular}{|l|l|r|r|r|r|}
\hline \multicolumn{1}{|c|}{ Species } & & XU1 & XU2 & XU3 & XU4 \\
\hline \multirow{2}{*}{ A. granosa } & MNI & 37 & 46 & 7 & - \\
\cline { 2 - 6 } & MNI \% & 54 & 40 & 54 & - \\
\hline \multirow{2}{*}{ S. cucullata } & MNI & 31 & 70 & 6 & 2 \\
\cline { 2 - 6 } & MNI \% & 46 & 60 & 46 & 100 \\
\hline \multirow{2}{*}{ All other species } & MNI & 12 & 9 & 1 & - \\
\cline { 2 - 6 } & MNI\% & 15 & 7 & 7 & - \\
\hline Total & MNI & $\mathbf{6 8}$ & $\mathbf{1 1 6}$ & $\mathbf{1 3}$ & $\mathbf{2}$ \\
\hline
\end{tabular}

Table 5. SM137sh shellfish composition.

\begin{tabular}{|l|l|r|}
\hline \multicolumn{1}{|c|}{ Species } & & Total \\
\hline \multirow{2}{*}{ A. granosa } & MNI & 687 \\
\cline { 2 - 3 } & MNI \% & 40 \\
\hline \multirow{2}{*}{ S. cucullata } & MNI & 961 \\
\cline { 2 - 3 } & MNI\% & 55 \\
\hline \multirow{2}{*}{ All other species } & MNI & 87 \\
\cline { 2 - 3 } & MNI \% & 5 \\
\hline Total & MNI & $\mathbf{1 7 3 5}$ \\
\hline
\end{tabular}


Table 6. SM137sh stone artefacts.

\begin{tabular}{|l|l|r|r|r|r|}
\hline Raw Material & \multicolumn{1}{|c|}{ Type } & \multicolumn{1}{c|}{$\begin{array}{c}\text { Cortex } \\
(\mathbf{\%})\end{array}$} & \multicolumn{1}{c|}{$\begin{array}{c}\text { Length } \\
(\mathbf{m m})\end{array}$} & \multicolumn{1}{c|}{$\begin{array}{c}\text { Width } \\
(\mathbf{m m})\end{array}$} & \multicolumn{1}{c|}{$\begin{array}{c}\text { Thickness } \\
(\mathbf{m m})\end{array}$} \\
\hline Quartz & Angular Fragment & $1-49$ & 15 & 9 & 6 \\
\hline Silcrete & Pebble & $50-99$ & 44 & 32 & 16 \\
\hline Quartz & Angular Fragment & $1-49$ & 26 & 15 & 7 \\
\hline Quartz & Flake & 0 & 16 & 12 & 5 \\
\hline Quartz & Flake & 0 & 21 & 13 & 5 \\
\hline Silcrete & Pebble & $50-99$ & 4.8 & 3.7 & 2.8 \\
\hline
\end{tabular}

Table 7. SM:140a excavation data.

\begin{tabular}{|l|r|r|r|}
\hline & \multicolumn{1}{|c|}{ XU1 } & \multicolumn{1}{c|}{ XU2 } & \multicolumn{1}{c|}{ XU3 } \\
\hline Unit depth $(\mathrm{cm})$ & 7.15 & 6.38 & 10.9 \\
\hline Gross weight $(\mathrm{g})$ & 19500 & 20000 & 27000 \\
\hline 6mm residue $(\mathrm{g})$ & 6950 & 9000 & 11500 \\
\hline Stones and rocks $(\mathrm{g})$ & 472 & 322 & 897 \\
\hline Charcoal $(\mathrm{g})$ & - & 1 & 2 \\
\hline Non-diagnostic shell $(\mathrm{g})$ & 2910 & 2499 & 1642 \\
\hline Diagnostic shell $(\mathrm{g})$ & 3211 & 2409 & 1985 \\
\hline
\end{tabular}

Table 8. SM:140a shellfish composition.

\begin{tabular}{|l|l|r|r|r|}
\hline \multicolumn{1}{|c|}{ Species } & & XU1 & XU2 & XU3 \\
\hline \multirow{2}{*}{ A. granosa } & MNI & 216 & 132 & 225 \\
\cline { 2 - 5 } & MNI\% & 44 & 22 & 64 \\
\hline \multirow{3}{*}{ M. hiantina } & MNI & 178 & 193 & 107 \\
\cline { 2 - 5 } & MNI\% & 36 & 32 & 30 \\
\hline \multirow{2}{*}{ S. cucullata } & MNI & 86 & 265 & 17 \\
\cline { 2 - 5 } & MNI\% & 17 & 44 & 5 \\
\hline \multirow{2}{*}{ All other species } & MNI & 12 & 11 & 5 \\
\cline { 2 - 5 } & MNI\% & 2 & 2 & 1 \\
\hline Total & MNI & $\mathbf{4 9 1}$ & $\mathbf{6 0 1}$ & $\mathbf{3 5 4}$ \\
\hline
\end{tabular}

here to be more representative of overall shellfish composition. The sample returned an age of 858(918)977 cal BP (Wk-12155) (Table 3) which is considered to represent the commencement of site accumulation.

Data on shellfish composition were obtained from both SM:137a (Table 4) and SM:137sh (Table 5). Because of the far larger sample, SM:137sh data are more representative of overall shellfish composition, however comparison with the undisturbed deposits excavated in SM:137a are nevertheless useful. A. granosa and $S$. cucullata are the most frequently occurring species by MNI for both sites while infrequently occurring species included M. hiantina, Nerita lineata, Volema cochlidium, Polymesoda erosa and Telescopium telescopium, all with a total combined MNI of $5.01 \%(n=87)$.

Six stone artefacts were recovered in the SM:137sh samples, including four on quartz and two on silcrete (Table 6). No formal tool types were identified.

\section{SM:140}

This small shell mound is located within the complex of mounds and shell scatters at Rhum Point (Figure 2b) and has maximum basal dimensions of $16 \mathrm{~m} \times 9 \mathrm{~m}$ and is up to $30 \mathrm{~cm}$ high. A single $0.5 \mathrm{~m}^{2}$ test pit (SM:140a) was excavated to a depth of $24 \mathrm{~cm}$ before culturally sterile bauxite substrate was reached. The deposit comprised large accumulations of whole and fragmented shellfish in a matrix of fine, dark organic soil. In section, the deposit comprised two primary layers: the upper $15 \mathrm{~cm}$ consisted of large amounts of highly fragmented shell differentiated from a lower layer $\sim 10 \mathrm{~cm}$ in depth with similar shellfish composition but larger proportions of fine ashy sediment. These are very coarse divisions only and no clear lenses or strata were identified. A summary of excavation data is provided in Table 7. A small sample of A. granosa valves were collected from the basal layer of SM:140a for radiocarbon dating and this returned an age span of 419(451)495 cal BP (Wk-1378) (Table 3).

Quantification by MNI of the shellfish retrieved in the $6 \mathrm{~mm}$ sieve residues of SM:140a indicated that A. granosa was not consistently the dominant species across all three spits. XU1 and XU2 were both composed of 32-36\% M. hiantina, 22-44\% A. granosa, and 17-44\% S. cucullata. A. granosa was the dominant species in XU3 representing $64 \%$ of shellfish MNI. Other species recovered include $N$. lineata, P. erosa, V. cochlidium and Balanus spp. Summary data for SM:140a are provided in Table 8.

Two silcrete artefacts were recovered from the surface of SM:140. One of these was an unmodified broken pebble and the second was a core with one flake scar. No artefacts were recovered from the excavated deposits. 


\section{SM:147}

SM:147 is the largest shell mound within the Rhum Point complex and sits atop the gradually sloping margin of the escarpment overlooking the Mission River (Figures 2b, 3 ), measuring $75 \mathrm{~m}$-long, $20 \mathrm{~m}$-wide and up to $1.5 \mathrm{~m}$-high. It is likely that this was the site sampled by Beaton as it is the only substantial shell mound located in this area.

This mound has had deposit removed from it in the recent past causing damage to a small portion of the site. However, the remaining deposit appears relatively undisturbed with several medium to large trees growing through it. Past disturbance, possibly associated with sampling by Beaton, had exposed a neat section approximately $1.5 \mathrm{~m}$-long across the densest part of the remaining deposit. Investigations at SM:147 involved cleaning back and recording this section, and then retrieving samples for radiocarbon dating and small sediment samples; no bulk samples of deposit were retrieved for analysis due to limited field time.

The stratigraphy of SM:147 is illustrated in Figure 4. The deposit is best described as consisting of layers of mostly whole shellfish with little sediment alternated with layers differentiated only by more fragmented shell and the presence of larger proportions of sediment. The dominant shellfish species was $A$. granosa, though other species including $S$. cucullata, $M$. hiantina, $P$. erosa and $N$. lineata were also observed. Several small distinct lenses occurred within the section, one of a dense accumulation of ash and charcoal, and the other a lens of fine brown soil.

A sample of A. granosa from the basal cultural layer produced an age span of 920(973)1018 cal BP (Wk13784) (Table 3). This site had also previously been dated by Beaton (Stone 1995:83) and when calibrated and corrected the resulting determination was 439(488)534 cal BP (ANU-4421) (Table 3). The relationship between these determinations is unclear due to the lack of contextual data for Beaton's sample.

\section{$S M: 136$}

SM:136 is a small shell mound within the Rhum Point group of sites (Figure 2b) and is approximately $18 \mathrm{~m} \mathrm{x}$ $14 \mathrm{~m}$ and up to $50 \mathrm{~cm}$ high. Apart from minor damage to its margins caused by clearance activities SM:136 was largely intact at the time this work was undertaken.

A north-south trench measuring $2 \mathrm{~m} \times 0.5 \mathrm{~m}$ was excavated across the centre of SM:136 in order to obtain a partial cross-section of a low shell mound deposit. This was excavated as four adjoining $0.5 \mathrm{~m}^{2}$ pits, rather than as a single trench. Only data from one of these - SM:136a is presented here as the other three had similar composition and stratigraphy and Pit $\mathrm{A}$ is considered to be representative of the entire site.

SM:136a was excavated in five spits to a depth of $\sim 32 \mathrm{~cm}$. This pit, along with the three adjacent pits, comprised an upper layer (A) of loosely-compacted shell in a dark earthy matrix that overlay a layer (B) (Figure 5) with less soil and more whole shellfish remains. Culturally sterile deposits (C) occur below this layer at approximately $20-25 \mathrm{~cm}$ below surface. The section drawing for SM:136 (Figure 5) suggests the upper layer has not accumulated horizontally, but rather, as a broad dome. This has seen the lower cultural layer (B) completely covered over by the upper layer (A).
Three radiocarbon samples of $A$. granosa were collected from the SM:136 section; however, only one of these was submitted for dating. This sample was obtained from the basal layer of the site and returned an age span of 148(256)305 cal BP (Wk-13785) (Table 3).

Shellfish data from SM:136a are presented in Table 9 and Figure 6. As shown, A. granosa did not comprise as significant a proportion of the MNI for each layer as was the case with other sites. However, it was still the most frequently occurring shellfish species at $76 \%$ in XU5 steadily dropping to around $50 \%$ in XU1. M. hiantina's contribution is initially low at a little under $14 \%$ in XU5 however over time this increases to almost 35\% in XU1. A slightly greater proportion of subspecies are also found in the upper layers when compared with the basal layers. A total of four fragments of crab claw (Scylla serrata) were identified within the test pits excavated on SM:136. These were all very small at less than $10 \mathrm{~mm}$-long and collectively weighed around $20 \mathrm{~g}$. No other non-molluscan faunal remains were identified.

Five stone artefacts were recovered from SM:136 with three of these located in SM:136a and the remaining two in the immediately adjacent pit SM:136b (Table 10). These included a single small mudstone flake, two quartz flakes, and a small quartz nodule. A small quartz pebble core with a single flake scar was also recovered.

SM:136a was the deepest deposit excavated at Bweening and also yielded the greatest proportions of non-molluscan faunal materials in XU1 and XU4. As such, these samples were selected for intensive analysis of $2 \mathrm{~mm}$ residues. A total of $1860 \mathrm{~g}$ of $2 \mathrm{~mm}$ residue was obtained from XU1 and 1250g from XU4, all of which was sorted for charcoal, stone artefacts, bone, crab or other diagnostic shellfish species. Summary data is provided in Table 11.

No bone and only four small fragments of crab shell weighing a combined total of $0.5 \mathrm{~g}$ were recovered from $2 \mathrm{~mm}$ residues sampled from SM:136a. Ceriths and a single complete but very small trochus shell were also recovered, the latter less than $0.5 \mathrm{~mm}$ in length. 51 diagnostic $M$. hiantina shellfish (MNI) were also identified and in total weighed less than $21 \mathrm{~g}$ (Table 11).

These results add little to our understanding of composition of SM136a, except to suggest that there is no archaeological evidence for anything beyond very minor amounts of non-molluscan fauna in this site. Given that no such materials were recovered in the $6 \mathrm{~mm}$ component of other sites or in inspections of accompanying $2 \mathrm{~mm}$ residues it is concluded here that this is likely to be the case for other sites excavated at Bweening. The presence of small proportions of $M$. hiantina in $2 \mathrm{~mm}$ residues are of minor significance, particularly when these are incorporated with $6 \mathrm{~mm}$ shellfish MNI data. The combination of $M$. hiantina data for both $2 \mathrm{~mm}$ and $6 \mathrm{~mm}$ residue increases the overall proportion of this species by $2.2 \%$ (from $34.9 \%$ to $37.1 \%$ ) in XU1 and by $2.2 \%$ (from $17.7 \%$ to $19.8 \%$ ) in XU4. In short, $6 \mathrm{~mm}$ residue analysis provides a sufficiently robust estimate of $M$. hiantina for the purposes of this study.

The presence of Ceriths in extremely small numbers raises the possibility that they were introduced to the site via cultural selection or as a by catch, for example, by being attached to other shellfish bought to the site. 


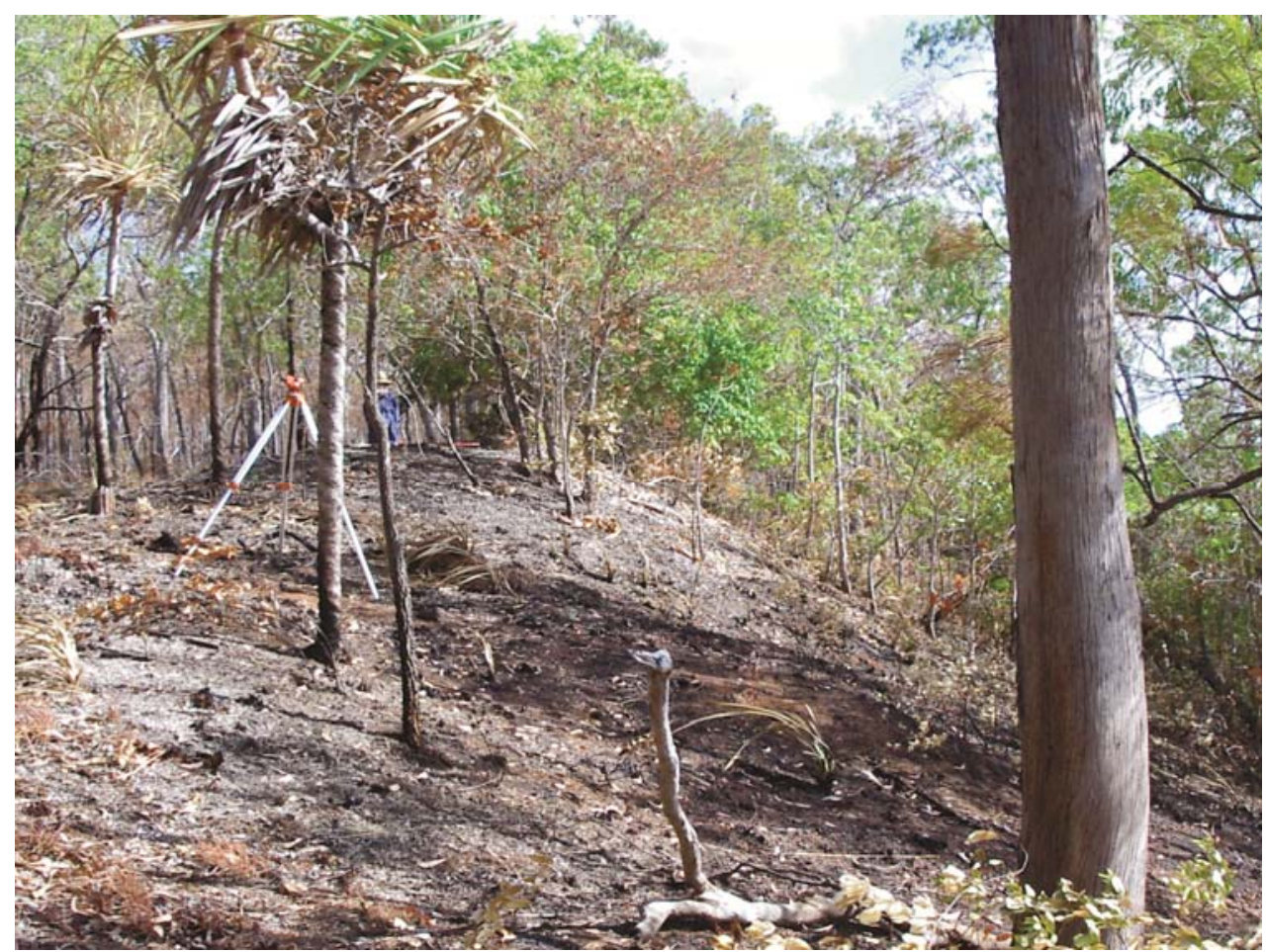

Figure 3. SM:147.

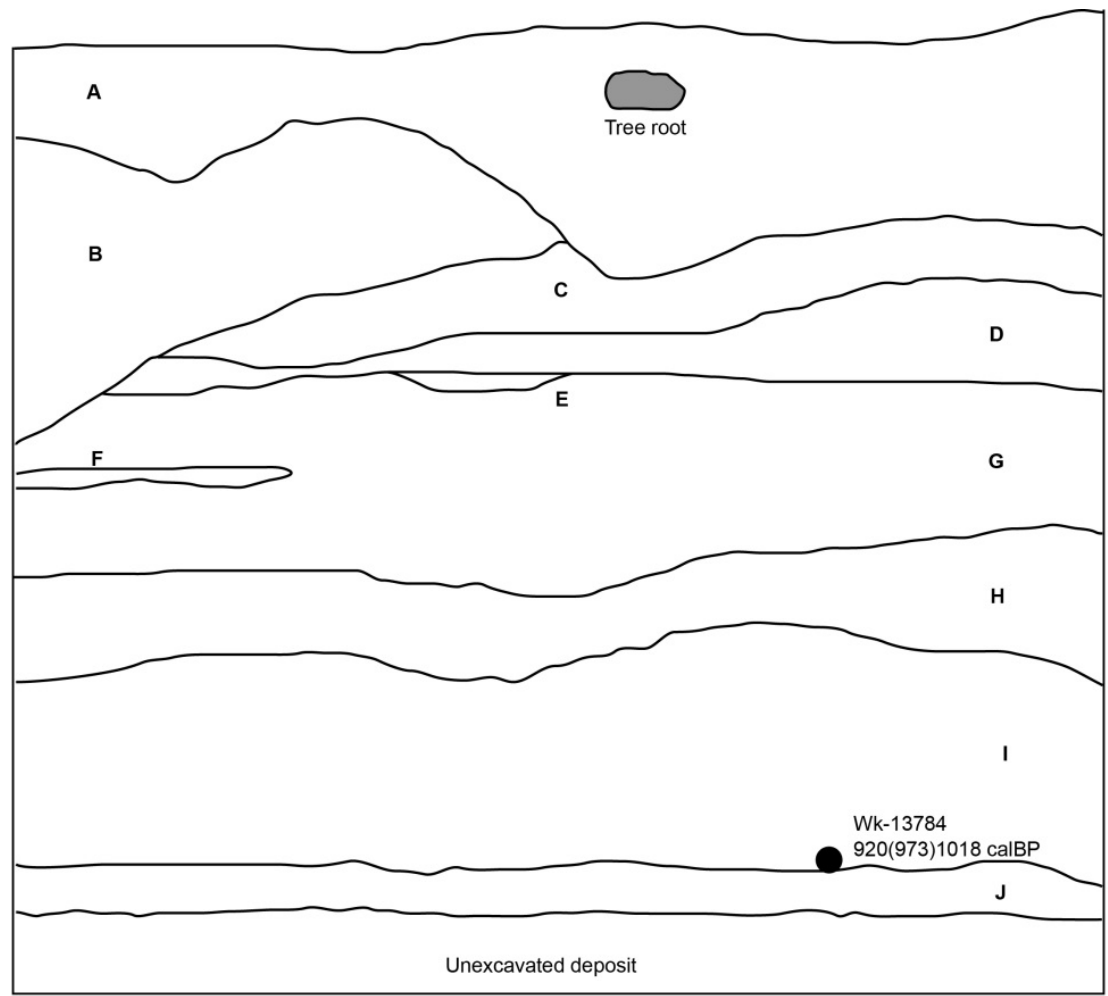

Scale: $1.5 \mathrm{~m}$

Layer descriptions:

A) Dense shell with matrix of fine black sediment containing frequent fine to medium roots. Heavily fragmented shell.

B) Loosely packed shell with little to no sediment. No roots and shell very white to yellow in colour.

C) Loosely packed shell in a matrix of fine ashy sediment with frequent roots.

D) Very fine yellow grey ash containing lower proportions of shell compared with other layers and occasional fine roots.

E) Thin lens of charcoal.

F) Thin layer of brown sediment containing smaller proportions of shell compared with other layers. Lacks roots.

G) Broad layer of shell containing large proportions of ash and fine brown soil.

H) Loosely compacted shell with moderate proportions of fine ashy sediment.

I) Loosely compacted shell with moderate proportions of fine ashy sediment, lighter colour than layer $\mathrm{H}$ with a tinge of red to yellow.

J) Bauxite laterite substrate.

Figure 4. Section drawing, SM:147. 


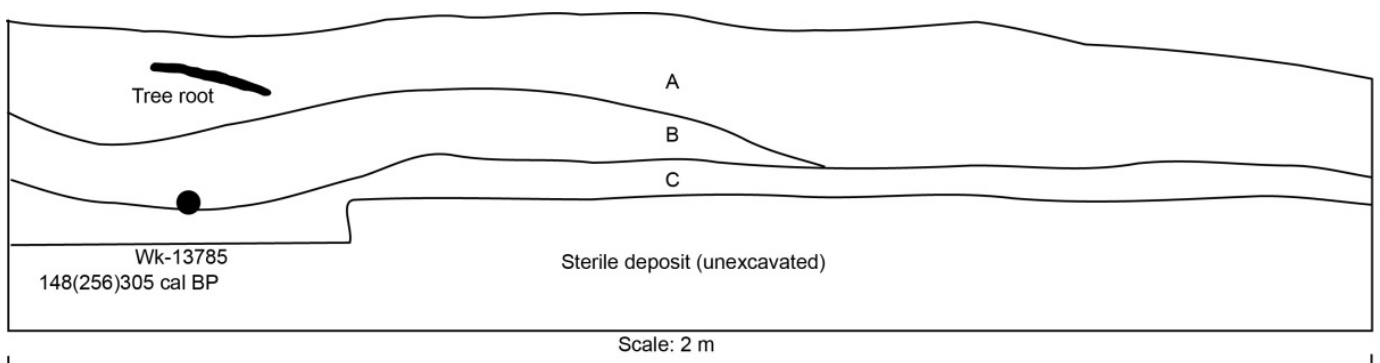

A) Loosely compacted shell with large proportions of dark earth sediment. Highly fragmented shell and frequent fine to medium sized roots.

B) Loosely compacted shell with low proportions of light red and orange coloured sediment. Occasional bauxite nodules and lower proportions of sediment compared with $A$.

C) Sterile layer. Highly compacted bauxite laterite substrate.

Figure 5. Section drawing, SM:136.

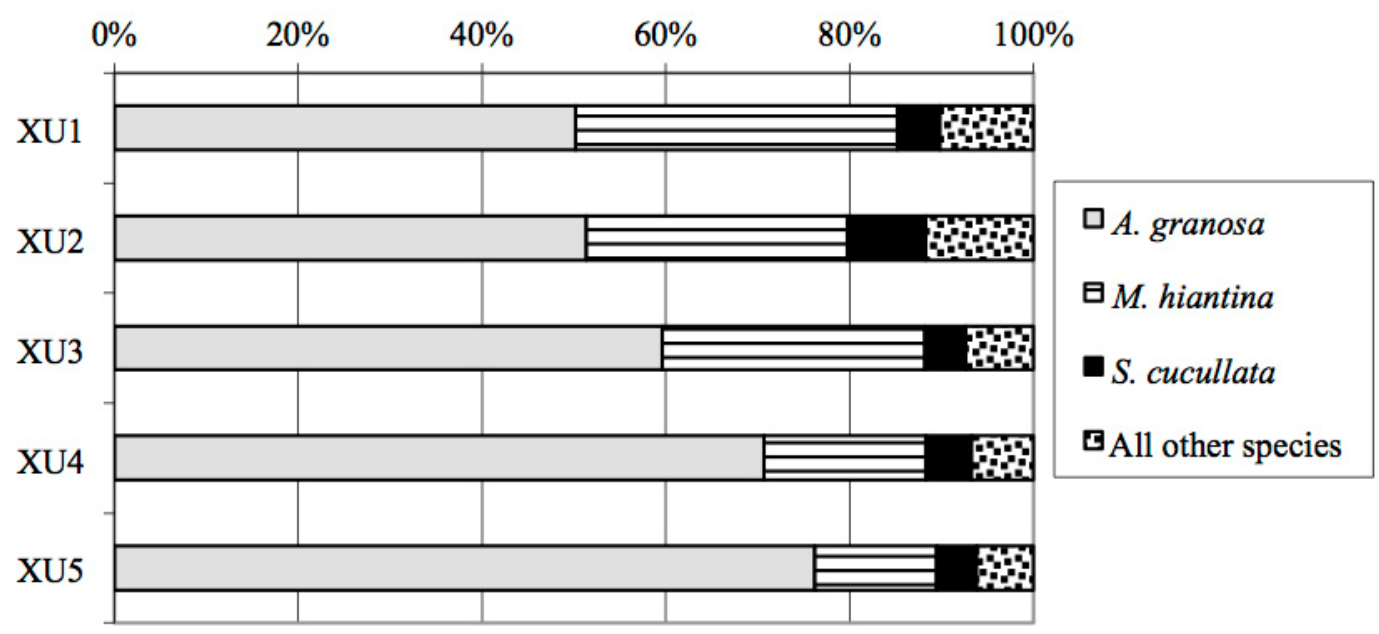

Figure 6. SM:136a shellfish MNI as a percentage of total excavation unit MNI.

Table 9. SM:136a shellfish composition.

\begin{tabular}{|l|l|r|r|r|r|r|}
\hline & & \multicolumn{1}{c|}{ XU1 } & \multicolumn{1}{c|}{ XU2 } & \multicolumn{1}{c|}{ XU3 } & \multicolumn{1}{c|}{ XU4 } & \multicolumn{1}{c|}{ XU5 } \\
\hline A. granosa & MNI & 393.32 & 508.89 & 577.27 & 623.84 & 278.74 \\
\hline & MNI\% & 50.22 & 51.34 & 59.61 & 70.64 & 76.18 \\
\hline M. hiantina & MNI & 274.00 & 282.00 & 276.50 & 156.00 & 48.50 \\
\hline & MNI\% & 34.98 & 28.45 & 28.55 & 17.66 & 13.26 \\
\hline S. cucullata & MNI & 36.50 & 84.00 & 43.00 & 44.00 & 16.00 \\
\hline & MNI\% & 4.66 & 8.47 & 4.44 & 4.98 & 4.37 \\
\hline Other species & MNI & 79.42 & 116.36 & 71.67 & 59.28 & 22.63 \\
\hline & MNI\% & 10.14 & 11.74 & 7.40 & 6.71 & 6.19 \\
\hline Total & & $\mathbf{7 8 3 . 2 4}$ & $\mathbf{9 9 1 . 2 4}$ & $\mathbf{9 6 8 . 4 4}$ & $\mathbf{8 8 3 . 1 2}$ & $\mathbf{3 6 5 . 8 7}$ \\
\hline
\end{tabular}

Table 10. SM:137 stone artefacts.

\begin{tabular}{|l|l|r|r|r|l|l|l|}
\hline $\begin{array}{c}\text { Raw } \\
\text { Material }\end{array}$ & $\begin{array}{c}\text { Artefact } \\
\text { Type }\end{array}$ & $\begin{array}{c}\text { Length } \\
(\mathbf{m m})\end{array}$ & $\begin{array}{c}\text { Width } \\
(\mathbf{m m})\end{array}$ & $\begin{array}{c}\text { Thickness } \\
(\mathbf{m m})\end{array}$ & \multicolumn{1}{|c|}{ Description } & Pit & Unit \\
\hline Quartz & Flake & 11 & 7 & 3 & Angular fragment & B & XU2 \\
\hline Mudstone & Flake & 15 & 9 & 4 & Angular fragment & B & XU2 \\
\hline Quartz & Core & 40 & 38 & 21 & Single flake scar & B & XU4 \\
\hline Quartz & Flake & 15 & 8 & 7 & Angular fragment & A & XU1 \\
\hline Quartz & Nodule & 24 & 14 & 13 & Unmodified & A & XU2 \\
\hline
\end{tabular}

Table 11. Summary of results of $2 \mathrm{~mm}$ analysis, SM136a.

\begin{tabular}{|c|c|c|c|c|c|c|c|c|c|c|c|c|}
\hline \multirow[t]{2}{*}{$\mathbf{X U}$} & \multirow{2}{*}{$\begin{array}{c}\begin{array}{c}2 \mathrm{~mm} \\
\text { Weight }\end{array} \\
(\mathrm{g})\end{array}$} & \multirow{2}{*}{$\begin{array}{c}\begin{array}{c}\text { Charcoal/ } \\
\text { Vegetation }\end{array} \\
(\mathrm{g}) \\
\end{array}$} & \multicolumn{2}{|c|}{ Crab } & \multicolumn{2}{|c|}{ Ceriths } & \multicolumn{2}{|c|}{ Land Snails } & \multicolumn{2}{|c|}{ M. hiantina } & \multicolumn{2}{|c|}{ Trochus } \\
\hline & & & $\#$ & (g) & (MNI) & (g) & (MNI) & (g) & (MNI) & (g) & (MNI) & (g) \\
\hline 1 & 1860 & 55 & 4 & $<0.5$ & 1 & $<0.5$ & 17 & $<2$ & 27 & 14 & 1 & $<1$ \\
\hline 4 & 1250 & 31 & - & - & 2 & $<0.5$ & 15 & $<1$ & 24 & 7 & - & \\
\hline
\end{tabular}




\section{SM:126}

SM:126 is a slight shell mound located at the edge of the escarpment at Rhum Point West (Figure 2a) where two $0.5 \mathrm{~m}^{2}$ pits were excavated. SM:126 itself is elongated and measures approximately $16 \mathrm{~m} \times 7 \mathrm{~m}$ in basal dimensions and up to $20 \mathrm{~cm}$ high. Pit SM:126a was excavated on an area of the site previously disturbed by earthmoving equipment; however, results are excluded here because the deposits were highly disturbed and minimal cultural material was recovered. The second pit, SM:126b, was placed on an undisturbed area of the mound near its deepest point.

Approximately $18 \mathrm{~cm}$ of deposit was excavated before a culturally sterile layer was reached. The substrate consisted of highly compacted lateritic soil with frequent bauxite pisoliths. The overlying deposit was a homogenous unit of whole and fragmented marine shell set within a matrix of fine, friable dark soil. Summary data are provided in Table 12. Two samples of $A$. granosa from SM:126b obtained from the lowermost and uppermost portions of the section were submitted for radiocarbon determinations. The lower determination returned a calibrated age of 423(463)511 cal BP (Wk12156) while the upper was $367(427) 492$ cal BP (Wk12157) (Table 3 ). The calibrated age spans suggests the site was deposited in a short time period of $\sim 19-55$ cal years.

A. granosa was the dominant species of shellfish by MNI, comprising between $82 \%$ and $93 \%$ of the MNI for each unit (Table 13, Figure 7). S. cucullata was the next most frequently occurring species, comprising at most $12 \%$ of the MNI of any unit. Other species recovered included $M$. hiantina, $P$. erosa, T. telescopium and Balanus spp.

\section{SM:123}

SM:123 is one of 10 discrete shell scatters clustered in a linear pattern along the edge of the escarpment at Rhum Point West (Figure 2a). All 10 scatters were between $1 \mathrm{~m}$ and $1.5 \mathrm{~m}$ in diameter and surface materials were predominantly A. granosa. A single $0.5 \mathrm{~m}^{2}$ test pit (SM:123a) was excavated revealing less than $5 \mathrm{~cm}$ of deposits before the sterile, compact bauxite laterite substrate was reached. Summary data are provided in Table 14. The cultural deposits - consisting primarily of compacted whole and fragmented shellfish remains were restricted to the upper $2-3 \mathrm{~cm}$ of this deposit. No artefacts or non-molluscan faunal remains were recovered. A sample of A. granosa shells were removed from the basal layer of test pit SM:123a for radiocarbon determination, returning an age span of 1(125)226 cal BP (Wk-12158).

Only small proportions of shellfish were recovered in SM123a and $A$. granosa was the most frequently occurring species with an MNI of 95 in XU1 and 40 in XU2 (Table 15). Other species recovered included $S$. cucullata and $N$. lineata.

\section{SM:116}

SM:116 is a small shell mound situated adjacent to the escarpment overlooking the Mission River 50m to the southwest of the Rhum Point West group of sites (Figure $2 \mathrm{a})$. Here the plateau is vegetated by open woodland and there is a $\sim 4 \mathrm{~m}$ sheer drop down to the shoreline where a narrow sandy beach occurs. Two $0.5 \mathrm{~m}^{2}$ pits were excavated on this site. SM:116a was excavated on an area previously damaged by clearance activity and only $4 \mathrm{~cm}$ of highly disturbed shell matrix deposit was recovered; this pit is not discussed further here. The second test pit, SM:116b, was excavated on an undisturbed area of SM:116 to a depth of $18 \mathrm{~cm}$ before the sterile bauxite laterite substrate was reached. The shell matrix deposit was between $6 \mathrm{~cm}$ and $15 \mathrm{~cm}$ in depth, the variation due to a natural depression in the substrate towards the southwest. The deposits comprised dense accumulations of whole and fragmented shell in a matrix of very fine, loose soil. Summary data resulting from the excavation are provided in Table 16. One sample of A. granosa was removed from the base of SM:116b for radiocarbon dating and returned a calibrated age span of 361(364)421 cal BP (Wk-12159).

SM:116b was predominantly composed of A. granosa (Table 17, Figure 8) and MNI values were all higher than $96 \%$, although it should be stated that the actual MNI of all diagnostic shellfish was at most 215 individuals in any layer.

A single, small angular quartz fragment was recovered and measured $6 \mathrm{~mm}$ by $12 \mathrm{~mm}$ in size. No other artefacts were recovered.

\section{SM:115}

SM:115 is located approximately $800 \mathrm{~m}$ to the southwest of the Rhum Point West group of sites and $8 \mathrm{~m}$ from the escarpment edge within open woodland (Figure 2). Prior to excavation this site had been heavily damaged by earthmoving equipment. However, the site had been recorded the year prior to this event and originally measured $30 \mathrm{~m}$ in diameter and up to $30 \mathrm{~cm}$ in height. Work on SM:115 aimed to recover information about the site after it had been damaged and included excavating a single test pit into the remaining few centimetres of intact deposit. Because of the extent of damage to this site, careful attention was paid to the spoil heaps where the bulk of the disturbed shell matrix deposit had been pushed. All data discussed below were generated via analysis of the spoil heaps. As such, no meaningful data on the stratigraphy and composition of SM:115 are available however summary data resulting from the sieving work on the spoil heaps (SM:115sh) are provided in Table 18. The weight values for the spoil heaps, discarded soil and $6 \mathrm{~mm}$ samples are inflated due to the high degree of intermixing of anthropogenic deposits with naturally occurring soil, ironstone, bauxite pisoliths and vegetation as a result of site disturbance. A $6 \%$ sample $(45 \mathrm{~kg})$ of the $6 \mathrm{~mm}$ materials were retained for more detailed analysis and sorting.

A single radiocarbon dating sample of A. granosa valves was obtained from $4 \mathrm{~cm}$ below the ground surface during the controlled excavation of pit SM:115a. These shells were firmly set within the bauxite laterite substrate and overlain by compacted shell matrix deposits. These basal deposits do not appear to have been disturbed by the clearance activity that had removed the bulk of the upper deposits of the site. The resulting age span for the basal layer of SM:115 was 154(283)395 cal BP (Wk-12160) (Table 3) and is considered here to represent the onset of site formation, despite the damage to the upper layers of the site. 
Table 12. SM:126b excavation data.

\begin{tabular}{|l|r|r|r|r|r|r|}
\hline & XU1 & \multicolumn{1}{|c|}{ XU2 } & \multicolumn{1}{c|}{ XU3 } & \multicolumn{1}{c|}{ XU4 } & \multicolumn{1}{c|}{ XU5 } & \multicolumn{1}{c|}{ XU6 } \\
\hline Unit depth $(\mathrm{cm})$ & 2.8 & 2.3 & 2.8 & 2.5 & 3.7 & 3.2 \\
\hline Gross weight $(\mathrm{g})$ & 8500 & 8500 & 7500 & 9500 & 9500 & 10500 \\
\hline 6mm weight $(\mathrm{g})$ & 3193 & 3996 & 3440 & 3633 & 1480 & 719 \\
\hline 2mm weight $(\mathrm{g})$ & 818 & 422 & 398 & 778 & 1467 & 2363 \\
\hline Stones $(\mathrm{g})$ & 64 & 12.5 & 20 & 31 & 255 & 546 \\
\hline Charcoal $(\mathrm{g})$ & 12 & 8 & 6.5 & 15 & 14 & 0.5 \\
\hline Soil $(\mathrm{g})$ & 4011 & 4418 & 3838 & 4411 & 2947 & 3082 \\
\hline Non-diagnostic shell $(\mathrm{g})$ & 1610 & 678 & 658 & 837 & 356 & 59 \\
\hline Diagnostic shell $(\mathrm{g})$ & 1445 & 3362 & 2672 & 2441 & 809 & 103 \\
\hline
\end{tabular}

Table 13. SM126b shellfish composition.

\begin{tabular}{|l|l|r|r|r|r|r|r|}
\hline \multicolumn{1}{|c|}{ Species } & & XU1 & \multicolumn{1}{c|}{ XU2 } & \multicolumn{1}{|c|}{ XU3 } & XU4 & XU5 & XU6 \\
\hline \multirow{3}{*}{ A. granosa } & MNI & 184 & 300 & 233 & 192 & 57 & 9 \\
\cline { 2 - 8 } & $\begin{array}{l}\text { MNI } \\
\%\end{array}$ & 93 & 93 & 86 & 83 & 88 & 82 \\
\hline \multirow{3}{*}{ S. cucullata } & MNI & 7 & 11 & 25 & 16 & 2 & 1 \\
\cline { 2 - 8 } & $\begin{array}{l}\text { MNI } \\
\%\end{array}$ & 3 & 6 & 12 & 8 & 1 & 1 \\
\hline \multirow{2}{*}{$\begin{array}{l}\text { All other } \\
\text { species }\end{array}$} & MNI & 7 & 11 & 13 & 25 & 6 & 1 \\
\cline { 2 - 8 } & $\begin{array}{l}\text { MNI } \\
\text { Total }\end{array}$ & 4 & 5 & 7 & 13 & 3 & 1 \\
\hline
\end{tabular}

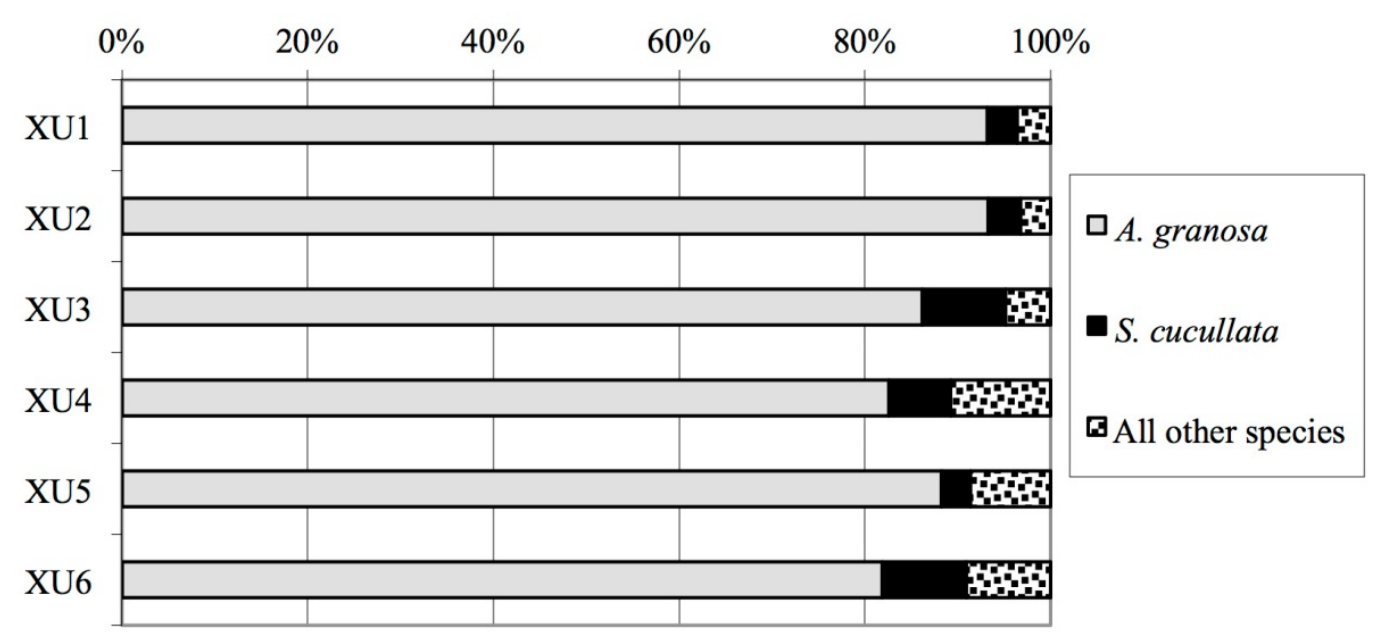

Figure 7. SM:126b shellfish MNI as a percentage of total excavation unit MNI.

Table 14. SM:123 excavation data.

\begin{tabular}{|l|r|r|}
\hline & \multicolumn{1}{|l|}{ XU1 } & \multicolumn{1}{l|}{ XU2 } \\
\hline Unit depth $(\mathrm{cm})$ & 2.1 & 1.4 \\
\hline Gross weight $(\mathrm{g})$ & 9500 & 7500 \\
\hline 6mm weight $(\mathrm{g})$ & 3096 & 1315 \\
\hline 2mm weight $(\mathrm{g})$ & 1666 & 432 \\
\hline Stones $(\mathrm{g})$ & 83 & 275 \\
\hline Charcoal $(\mathrm{g})$ & 9 & 13 \\
\hline Soil $(\mathrm{g})$ & 4762 & 1747 \\
\hline Non-diagnostic shell $(\mathrm{g})$ & 1394 & 432 \\
\hline Diagnostic shell $(\mathrm{g})$ & 1532 & 586 \\
\hline
\end{tabular}


Table 15. SM:123 shellfish composition.

\begin{tabular}{|l|l|r|r|}
\hline \multicolumn{1}{|c|}{ Species } & & XU1 & XU2 \\
\hline A. granosa & MNI & 95 & 40 \\
\hline & MNI \% & 83.3 & 88.9 \\
\hline S. cucullata & MNI & 18 & 4 \\
\hline & MNI \% & 15.8 & 8.9 \\
\hline N. lineata & MNI & 1 & 1 \\
\hline & MNI \% & 0.9 & 2.2 \\
\hline Total & MNI & $\mathbf{1 1 4}$ & $\mathbf{4 5}$ \\
\hline
\end{tabular}

Table 16. SM116b excavation data.

\begin{tabular}{|l|r|r|r|r|r|r|}
\hline & \multicolumn{1}{|c|}{ XU1 } & \multicolumn{1}{c|}{ XU2 } & \multicolumn{1}{c|}{ XU3 } & \multicolumn{1}{c|}{ XU4 } & \multicolumn{1}{c|}{ XU5 } & \multicolumn{1}{c|}{ XU6 } \\
\hline XU depth $(\mathrm{cm})$ & 3.2 & 2.8 & 2.7 & 2.9 & 2.7 & 3.4 \\
\hline Gross weight $(\mathrm{g})$ & 10000 & 10000 & 9500 & 9000 & 9000 & 10000 \\
\hline 6mm weight $(\mathrm{g})$ & 2882 & 1975 & 729 & 528 & 275 & 229 \\
\hline 2mm weight $(\mathrm{g})$ & 1277 & 1195 & 2011 & 1601 & 1502 & 1683 \\
\hline Stones $(\mathrm{g})$ & 20 & 94 & 340 & 198 & 181 & 200 \\
\hline Charcoal $(\mathrm{g})$ & - & 2 & 1 & 1 & 1 & - \\
\hline Soil $(\mathrm{g})$ & 5841 & 6830 & 6760 & 6871 & 7223 & 8088 \\
\hline Non-diagnostic shell $(\mathrm{g})$ & 1416 & 717 & 153 & 80 & 25 & 15 \\
\hline Diagnostic shell $(\mathrm{g})$ & 1414 & 1132.5 & 231.3 & 198 & 23 & 15 \\
\hline
\end{tabular}

Table 17. SM:116b shellfish composition.

\begin{tabular}{|l|l|r|r|r|r|r|r|}
\hline \multicolumn{1}{|c|}{ Species } & & \multicolumn{1}{c|}{ XU1 } & \multicolumn{1}{c|}{ XU2 } & \multicolumn{1}{c|}{ XU3 } & \multicolumn{1}{c|}{ XU4 } & \multicolumn{1}{c|}{ XU5 } & \multicolumn{1}{c|}{ XU6 } \\
\hline A. granosa & MNI & 212 & 151 & 35 & 27 & 9 & 3 \\
\hline & MNI \% & 99 & 97 & 96 & 96 & 100 & 100 \\
\hline Other species & MNI & 3 & 4.5 & 1.5 & 1 & - & - \\
\hline & MNI \% & 1 & 3 & 4 & 4 & - & - \\
\hline Total & MNI & $\mathbf{2 1 5}$ & $\mathbf{1 5 6}$ & $\mathbf{3 6 . 5}$ & $\mathbf{2 8}$ & $\mathbf{9}$ & $\mathbf{3}$ \\
\hline
\end{tabular}

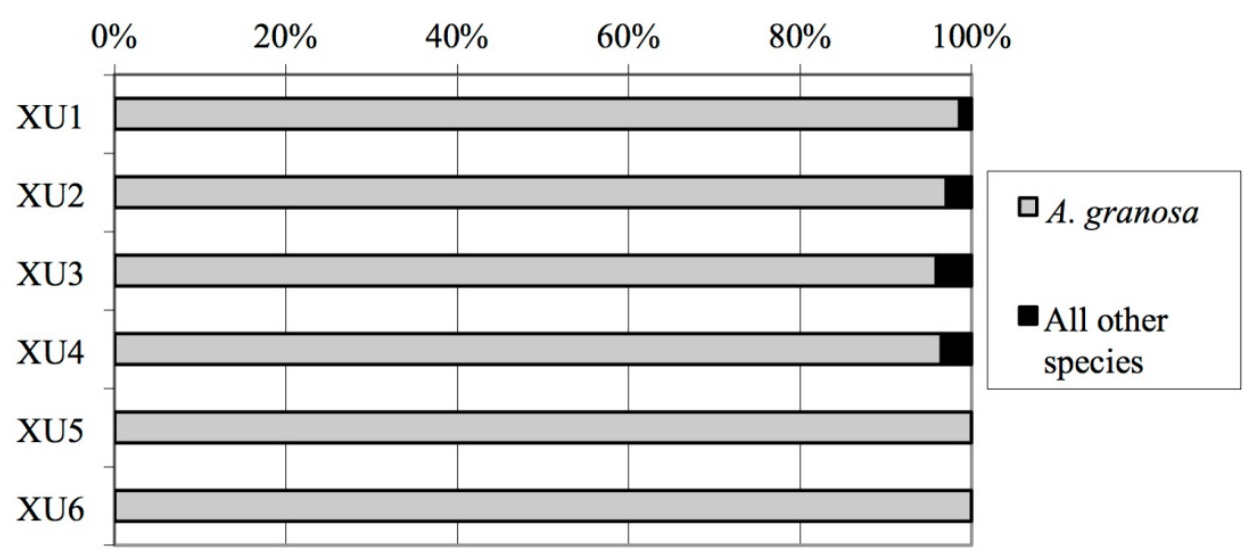

Figure 8. SM:116 shellfish MNI as a percentage of total excavation unit MNI.

Table 18. SM:115sh summary data.

\begin{tabular}{|l|r|}
\hline \multicolumn{1}{|c|}{ Material } & \multicolumn{1}{c|}{$\begin{array}{c}\text { Weight } \\
(\mathbf{k g})\end{array}$} \\
\hline Gross Weight & 1059 \\
\hline Discarded soil & 308 \\
\hline Gross 6mm weight & 751 \\
\hline 6mm analysed & 45.58 \\
\hline Non-diagnostic shell & 29.13 \\
\hline
\end{tabular}


Table 19. SM:115 shellfish MNI.

\begin{tabular}{|l|r|r|}
\hline \multicolumn{1}{|c|}{ Species } & MNI & \multicolumn{1}{c|}{$\mathbf{\%}$} \\
\hline A. granosa & 1472 & 95.52 \\
\hline S. cucullata & 31 & 2.01 \\
\hline M. hiantina & 20 & 1.30 \\
\hline P. erosa & 1 & 0.06 \\
\hline V. cochlidium & 4 & 0.26 \\
\hline N. lineata & 5 & 0.32 \\
\hline T. telescopium & 4 & 0.26 \\
\hline Land snail (unidentifiable species) & 1 & 0.06 \\
\hline Ellobium sp. & 1 & 0.06 \\
\hline Balanus sp. & 1 & 0.06 \\
\hline Total MNI & $\mathbf{1 5 4 1}$ & \\
\hline
\end{tabular}

Table 20. SM:115 stone artefacts.

\begin{tabular}{|l|l|c|c|c|c|l|}
\hline $\begin{array}{c}\text { Raw } \\
\text { Material }\end{array}$ & Artefact Type & $\begin{array}{c}\text { Cortex } \\
(\mathbf{\%})\end{array}$ & $\begin{array}{c}\text { Length } \\
(\mathbf{m m})\end{array}$ & $\begin{array}{c}\text { Width } \\
(\mathbf{m m})\end{array}$ & $\begin{array}{c}\text { Thickness } \\
(\mathbf{m m})\end{array}$ & \multicolumn{1}{c|}{ Comments } \\
\hline Quartz & Split pebble & $50-99$ & 40 & 20 & 15 & \\
\hline Quartz & Flake & $1-49$ & 12 & 8 & 3 & $\begin{array}{l}\text { Bulb of percussion and } \\
\text { striking platform }\end{array}$ \\
\hline Quartz & Flake & $1-49$ & 14 & 12 & 6 & Striking platform only \\
\hline Quartz & Flake & $50-99$ & 26 & 16 & 9 & No diagnostic features \\
\hline
\end{tabular}

The $6 \%$ sample of $6 \mathrm{~mm}$ residues obtained from sorting of the SM:115sh samples yielded large proportions of A. granosa with only very low proportions of other shellfish species (Table 19). The MNI for A. granosa recovered in the sample represented $95.5 \%$ of the total diagnostic shell sample. S. cucullata and M. hiantina were the next most frequently occurring species (1-2\%) along with a range of other subspecies that occurred in negligible proportions. A single, small fragment of mud crab (S. serrata) claw measuring less than $10 \mathrm{~mm}$ in length was recovered during the sorting of the $6 \mathrm{~mm}$ residue sample. No other faunal materials were recovered.

Four stone artefacts were recovered from the $6 \mathrm{~mm}$ sieve residues (Table 20), including some identified during sorting both in the field and the laboratory. These included three small quartz flakes and a small quartz split pebble. No other artefacts were recovered despite the very large amounts $(\sim 1059 \mathrm{~kg})$ of $6 \mathrm{~mm}$ residues that were hand-sorted in the field.

\section{SM:114}

SM:114 is a broad, low shell mound deposit approximately $35 \mathrm{~m}$ in diameter that lies immediately adjacent to the escarpment overlooking the Mission River (Figure 2). The surrounding vegetation is a mixture of open woodland and closed dry notophyll vine forest. A narrow sandy beach and tidal mudflat occur at the foot of the escarpment. Sometime during the 1970s a small fishing hut was built $15 \mathrm{~m}$ to the north of SM:114. This was removed in 2002 and in the process minor damage was inflicted upon the northern and western margins of SM:114. Three $0.5 \mathrm{~m}^{2}$ test pits were excavated on SM:114. Two of these (SM:114a and SM:114b) were on heavily disturbed portions of the site yielding little useful data and are thus not discussed further here. The third, SM: $114 c$, was located on an undisturbed area of the site and results are reported here.
SM:114c was excavated to a depth of $18 \mathrm{~cm}$ and culturally sterile bauxite laterite substrate was reached at approximately $16 \mathrm{~cm}$ below surface. The upper $16 \mathrm{~cm}$ of deposit consisted of loosely-packed whole and fragmented shellfish remains dominated by A. granosa in a matrix of fine, friable soil. Summary data for the site are shown in Table 21. No distinct strata were identified within SM:114c. A single sample of A. granosa was obtained from the base of SM:114c for radiocarbon determinations and this returned a calibrated age span of 338(404)461 cal BP (Wk-12161) (Table 3).

A. granosa was the dominant shellfish species recovered in the SM:114c test pit (Table 22). This varied between $87 \%$ and $100 \%$ of the total MNI for each excavation unit. Other species recovered included $S$. cucullata, N. lineata, M. hiantina and V. cochlidium.

Two small quartz fragments less than $1.5 \mathrm{~mm}$ in length were recovered in SM:114c. Both had no diagnostic features, were highly angular and had little to no cortex.

\section{Discussion}

The Bweening investigation was undertaken in order to understand the developmental processes associated with mound formation via an investigation of the stratigraphy, chronology and composition of a suite of shell matrix sites. Here, key results are synthesised and a preliminary model for shell mound development is proposed.

\section{Stratigraphy}

Shell matrix features observed at Bweening can be distinguished into three broad groups based on their stratigraphic and compositional characteristics. Firstly, light shell scatters have essentially no stratigraphic variation. The SM:123 shell scatter had relatively simple stratigraphy consisting of low proportions of shellfish set within natural substrates. These deposits typically were set within very low-density scatters of A. granosa. 
Table 21. SM:114c excavation data.

\begin{tabular}{|l|r|r|r|r|}
\hline & \multicolumn{1}{|c|}{ XU1 } & \multicolumn{1}{c|}{ XU2 } & \multicolumn{1}{c|}{ XU3 } & \multicolumn{1}{c|}{ XU4 } \\
\hline Unit depth $(\mathrm{cm})$ & 5.15 & 6.12 & 6.2 & 1.8 \\
\hline Gross weight $(\mathrm{g})$ & 18500 & 19000 & 23500 & 6000 \\
\hline $6 \mathrm{~mm}$ weight $(\mathrm{g})$ & 5229 & 5270 & 5124 & 835 \\
\hline $2 \mathrm{~mm}$ weight $(\mathrm{g})$ & 3095 & 3619 & 4228 & - \\
\hline Stones $(\mathrm{g})$ & 1250 & 1758 & 3605 & 749 \\
\hline Soil $(\mathrm{g})$ & 10176 & 10111 & 14148 & 5165 \\
\hline Non-diagnostic shell $(\mathrm{g})$ & 2813 & 1252 & 607 & 44 \\
\hline Diagnostic shell $(\mathrm{g})$ & 1059 & 2140 & 813 & 38 \\
\hline
\end{tabular}

Table 22. SM:114c shellfish composition.

\begin{tabular}{|l|l|r|r|r|r|}
\hline \multicolumn{1}{|c|}{ Species } & & XU1 & XU2 & \multicolumn{1}{c|}{ XU3 } & \multicolumn{1}{c|}{ XU4 } \\
\hline A. granosa & MNI & 95 & 262 & 103 & 7 \\
\hline & MNI \% & 87 & 96 & 94 & 100 \\
\hline Other species & MNI & 6 & 7 & 2 & - \\
\hline & MNI \% & 6 & 3 & 2 & - \\
\hline Total & MNI & $\mathbf{1 0 9}$ & $\mathbf{2 7 2}$ & $\mathbf{1 0 9}$ & $\mathbf{7}$ \\
\hline
\end{tabular}

The second stratigraphic pattern occurs on low shell mound sites and consists of a dense shell-rich layer up to $30 \mathrm{~cm}$-thick overlying natural strata. Such sites had little internal layering apart from several instances of a thin layer of highly fragmented shell across the site surface. Fine sediment in these deposits was visibly higher, presumably as a result of the low profile of these sites and their higher exposure to fire, vegetation growth and windborne deposition of sediments. Sites with these sorts of characteristics included SM:140, SM:126, SM:116 and $\mathrm{SM}: 114$. Although largely destroyed, it is likely that SM:136 and SM:115 would have also fallen into this category based on their size, form and what is known about their composition.

The third broad stratigraphic pattern noted in shell matrix sites at Bweening is perhaps best termed as 'classic' shell mound stratigraphy. These include deposits that are comprised of alternating layers of sediment rich and sediment poor deposits, all dominated by very large proportions of shellfish remains. The two excavated examples at Bweening included SM:146 and SM:140, and are capped by a surface layer of more fragmented shell with greater proportions of fine roots. This upper layer is proposed here to reflect greater exposure to weathering, bioturbation and other taphonomic processes influencing shell integrity.

Stones and rocks were recovered in all shell matrix sites, with proportions of these materials generally increasing with proximity to the natural bauxite substrates. Two types of stone were encountered in these deposits: bauxite pisoliths and ironstone. Both of these materials are common on the bauxite plateaus and likely to have been incorporated through intermixing with natural substrates in the basal layers of shell matrix sites.

\section{Chronology}

All of the more substantial shell matrix deposits within the Bweening study area now have basal radiocarbon determinations that enable development of at least a preliminary chronology of site development in the area. Summary data on calibrated basal dates for shell matrix deposits in this area are presented in Figure 9 and original data are presented in Table 3.

\section{Temporal Patterns}

The earliest features in the Bweening study area are SM:137 and SM:147 at Rhum Point with calibrated age spans of $\sim 858-1018$ cal BP. SM:147 is the largest feature in the study area and the larger volume of deposit is consistent with it having an earlier age than other more minor shell matrix deposits. SM:137 was extensively damaged prior to excavation taking place; however, the fact that the sample was removed from undisturbed deposits suggests that this determination is a reliable estimate for the onset of site formation. Figure 9 shows that the majority of Bweening sites commenced forming after $\sim 500$ cal BP. It is unlikely that any of the undated features have basal ages earlier than this because as noted above these were all low density deposits.

After around $\sim 500$ cal BP discard commenced at SM:136 and SM:140 and it is likely that the numerous small shell scatters around SM:140 were deposited after this time. This concentration of activity may represent the early stages in the formation of a new, elongated shell mound similar to SM:147. These features all cluster around one central point in the landscape and occur in much the same setting as the larger SM:147: that is, immediately overlooking the escarpment and oriented in an elongated fashion, parallel to the shore. This is proposed here to be illustrative of the early phases of mound formation: numerous discrete individual discard events centred around a specific point in the landscape.

Three basal determinations were obtained from the Rhum Point West area revealing a similar scenario to that occurring at Rhum Point. Of specific interest here is the equidistant arrangement of small groups of sites approximately $100 \mathrm{~m}$ apart, including the northern-most site SM:196, a second concentration of 10 small shell scatters (SM:117-127), and a midden site SM:116 to the south. All of these features appeared only after $\sim 427 \mathrm{cal}$ BP, the earliest being SM:126 [376(427)492 cal BP (Wk12156)], followed by the commencement of SM:116 


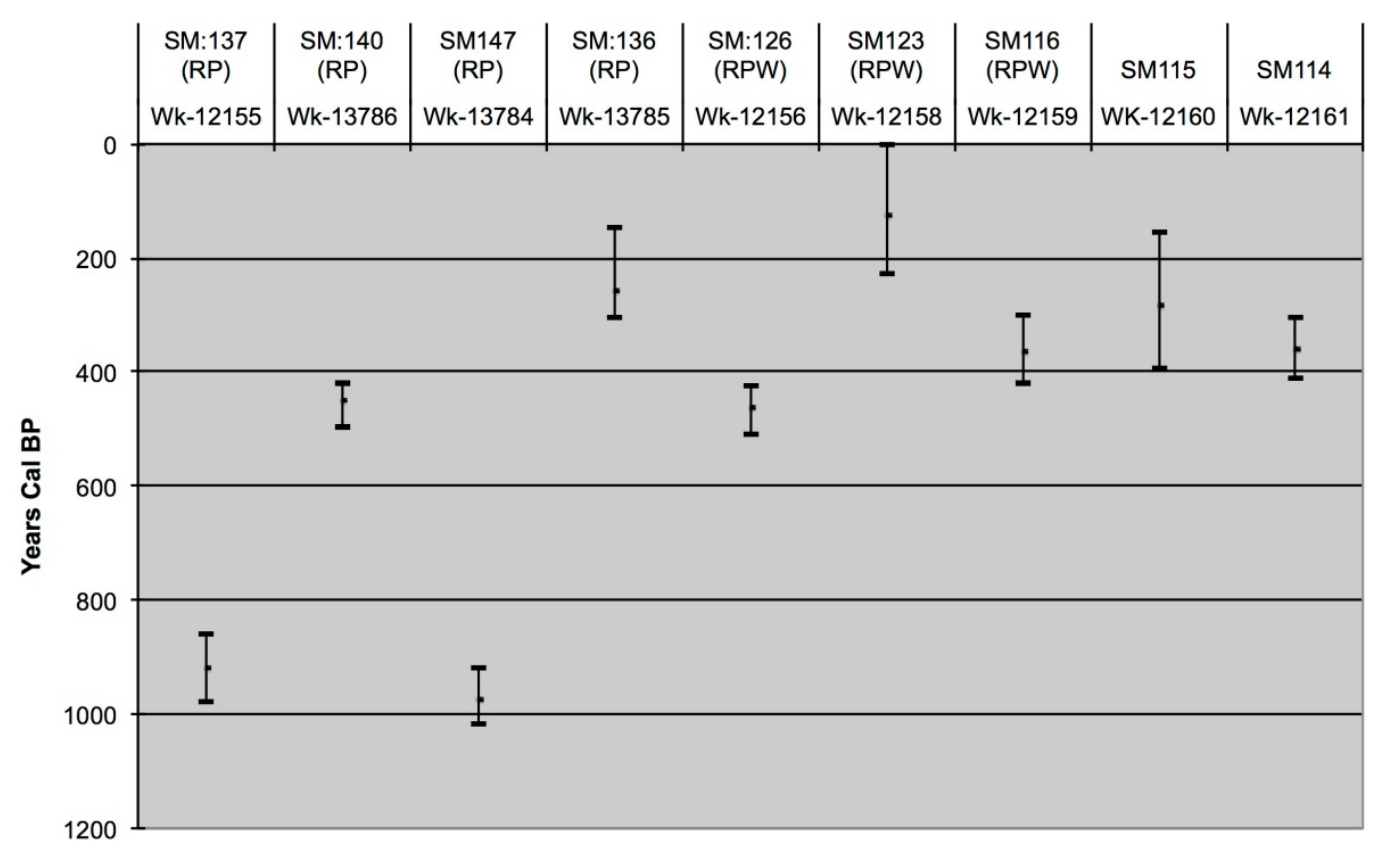

Figure 9. Basal calibrated age spans, Bweening. RP=Rhum Point; RPW=Rhum Point West. Basal determinations only.

[298(364)421) cal BP (Wk-12159)] and the more recent formation of the low density shell scatter in the central group of sites [1(125)226) cal BP (Wk-12158]. Significantly, an upper determination on the northern shell mound suggests it was abandoned around or after $376(427) 492$ cal BP (Wk-12157), or prior to the commencement of either SM:116 or SM:123 and suggesting possible successional development of sites in this area.

The most southern sites are also relatively young at 303(361)410 (Wk-12161, SM:114) and 154(283)395 (Wk-12160, SM:115), respectively. These sites thus form in the same period in which the bulk of Bweening coastal sites began forming and reveal that despite the existence of other larger mound deposits further to the northeast, new mound sites were being established in locations that were not a significant distance from pre-existing sites. Extremely local factors were clearly important in the context of the discard events associated with mound development.

Several important points can be drawn from the developmental sequence outlined for Bweening. First, spatial and chronological patterns at Rhum Point and Rhum Point West illustrate the early phases of shell mound formation and provide a clue to the scale of individual discard events that contributed to mound formation. This is best exemplified by the central cluster of 10 shell scatters in an ellipsoidal arrangement and oriented along the escarpment edge at Rhum Point West and the similar cluster of scatters near SM:140 at Rhum Point. In both cases, multiple small $1-2 \mathrm{~m}$ diameter scatters of shell occur in close proximity to one another and point to the possibility that these scatters each represent a very short-term activity area, possibly an individual discard event or series of events. It is of course unclear whether these individual features are contemporaneous, for example reflecting a single period of shellfishing activity over a series of days or weeks or repeat use over months or longer. However, it does provide an important insight on the early phases of mound development since ongoing small-scale discard events focussed on a central point in this way would see the eventual formation of a new mound feature. Importantly, the shell scatters are distributed in an elongated pattern oriented towards the shoreline, thus pointing to the early development of a shore-parallel elongated mound.

Second, both the Rhum Point and Rhum Point West sites show a pattern of shifting discard focus at the local level through time. At Rhum Point West, initial discard occurred to the north at SM:126 followed by its apparent abandonment, with a subsequent focus on SM:116, 200m to the southwest. No upper age is available for SM:116 however a short period of usage is likely because it consists of relatively little deposit compared to the larger SM:126. The implication of this is that SM:116 was also used for a short period before deposition focussed in the area around SM:123 ceased before a new mound could develop. In short, the deposits at Rhum Point West were deposited in succession over a period of approximately 300 years with discard patterns shifting at the local level, within an approximately $100 \mathrm{~m}$ length of the escarpment edge. This shifting focus of discard activity through time is also evident at Rhum Point, but over a longer period of time with the emergence of a new range of sites after c.500 cal BP despite pre-existing deposits.

Third, the spatial and chronological data show that where multiple low density scatters develop there is also a tendency for a central discard foci to be established, evidenced by a low, roughly circular dome mound. The cluster of scatters around the more centrally located SM:140 at Rhum Point and the clustering of discrete scatters (SM:120-123) at Rhum Point West both typify this. It is proposed then that repeated discard within a specific area eventually leads to the formation of a central discard focus and the emergence of new mounds. With time, it is conceivable that these low dome mounds and surrounding discrete scatters coalesced further to form larger elongated mounds such as SM:147. 


\section{Phases of Mound Development}

The stratigraphic and chronological data for the full range of shell matrix sites at Bweening allows for a clearer picture of shell mound development processes to be outlined. A model with three distinct phases of mound formation can now be proposed:

Incipient Shell Mounds: Bailey (1977) noted the occurrence of incipient mounds in his early work however the term has generally been loosely applied to small concentrated shell matrix deposits. Here it is proposed that the term be applied specifically to distinct shell scatters concentrated around a central point in the landscape. These are interpreted here as representing the early stages of formation of shell mounds.

Intermediate Shell Mounds: A number of the shell matrix sites at Bweening are best considered as intermediate mounds. These are low in height $(<30 \mathrm{~cm})$ or not mounded at all (e.g. SM:116), and their stratigraphy lacks any significant internal variation. These sites likely reflect the intermediate stages of mound formation after the various discrete deposits at an incipient mound merged to form a homogenous deposit, but where deposition was insufficient to allow for the development of stratification within the site.

Classic Shell Mounds: The third phase of mound formation is the formation of shell mounds proper, which are characterised by sufficiently deep deposits to form distinct stratigraphic layers as a result of unique discard histories and natural site formation processes influencing the site. These discrete but often coarse strata are argued here to reflect the same kind of local spatial variations in discard evident at Bweening; that is, by virtue of their size larger mounds allow for a shifting focus in discard activity across the surface of the site. Both SM:136 and SM:147, as well as larger sites excavated elsewhere (see examples in Bailey et al. 1994) indicate that different portions of these sites have different depositional histories, as well as a cessation of discard in particular areas allowing for other kinds of stratigraphic features to develop.

The basic 'building blocks' of large mounds were spatially discrete discard activities that initially led to small groups of concentrated shell scatters - or incipient mounds - that with time coalesced to form low, intermediate shell mounds. It is clear from even the coarse chronological data presented here that the spatial focus of these discard activities regularly shifted even within particular groups of sites, and that these shifts appear to occur both at long-term time scales, over centuries, but also seemingly at a decadal level. The existence of a substantial mound deposit at a particular locale does not rule out the occurrence of other incipient or intermediate shell mounds forming nearby. At Rhum Point and Rhum Point West, new mounds developed close to pre-existing mounds suggesting complexities in local patterns of site use requiring further investigation, and two key questions can be raised here. First, at the local level, what economic, social, cultural and environmental factors led to both initial and ongoing focussed discard around particular points in the landscape, leading to the development of incipient and intermediate shell mounds? Second, at a broader level across the Bweening study area, what factors influenced localised shifts in discard activity or the emergence of new mound complexes, such as Rhum Point West?

\section{Composition}

The most frequently occurring shellfish species across all Bweening sites are A. granosa, $M$. hiantina and $S$. cucullata (Table 23, Figure 10). Importantly, to compare MNI data across all sites in this way ignores variation in shellfish representation over time at particular sites. Not all sites are appropriate for considering changes in shellfish composition over time because of the limited depth of deposits or the use of spoil heap data (i.e. SM:123 [shell scatter], SM:137 [spoil heap] and SM:115 [spoil heap]). However, in sites with appropriate data, it is evident that the proportions of shellfish species for the entire site are consistent with the data for each excavation unit and in no instances are specific dominant species entirely replaced by other species over time. This is likely to be partly a result of the short time-spans over which mounds have formed.

Greatest shellfish diversity occurs in the three sites at Rhum Point. Uniquely, the SM:137 deposits are marginally dominated by $S$. cucullata (55\%) with $A$. granosa less well represented, although still present in substantial quantity (39\%). SM:140 has similar proportions of A. granosa, S. cucullata and M. hiantina, although the latter is present in slightly greater proportions overall. SM:136a is dominated by A. granosa however $M$. hiantina comprises a significant proportion of deposits overall at almost $30 \%$ of total MNI.

Figure 10 shows that all sites away from Rhum Point are predominantly composed of A. granosa, which represents between $84-97 \%$ of total shellfish MNI. The proportions of subspecies in these sites, in all cases, were less than $10-15 \%$. The highest proportions of other species were noted in the shell scatter SM:123 which consisted of only around 159 individuals. This raises several important questions: why do the sites with the largest variation in dominant shellfish species occur at Rhum Point; how does that relate to longer trends in site formation outlined above, and finally; is there an environmentally-oriented explanation for the more substantial deposits at Rhum Point compared with other areas along this part of the coastline?

Both $A$. granosa and $M$. hiantina inhabit the lower intertidal mudflat zone. In contrast, $S$. cucullata is more frequently found in the intertidal zone around rocky headlands, rock-strewn shorelines as well as the seaward margins of some mangrove forests where it attaches itself to mangrove roots. $N$. lineata, $P$. erosa, $V$. cochlidium and T. telescopium commonly inhabit the intertidal zone of mangrove forests with the latter three species found on the muddy substrates while $N$. lineata lives on mangrove roots. As described earlier, extensive mudflats occur along the entire coastline in the Bweening study area, and across all areas extending $100 \mathrm{~m}$ or more offshore at low tides. Conversely, rocky headlands, rock strewn shorelines and mangrove communities are more restricted in their distribution, with the area around Rhum Point evidencing the largest examples of these types of microenvironments within the study area. 
Table 23. Shellfish composition data for Bweening sites.

\begin{tabular}{|c|c|c|c|c|c|c|c|c|c|c|c|c|c|c|c|c|}
\hline \multirow[t]{3}{*}{ Species } & \multicolumn{6}{|c|}{ Rhum Point } & \multicolumn{6}{|c|}{ Rhum Point West } & \multicolumn{4}{|c|}{ Other } \\
\hline & \multicolumn{2}{|c|}{ SM:137sh } & \multicolumn{2}{|c|}{ SM:136a } & \multicolumn{2}{|c|}{ SM:140 } & \multicolumn{2}{|c|}{ SM:126 } & \multicolumn{2}{|c|}{ SM:123 } & \multicolumn{2}{|c|}{ SM:116 } & \multicolumn{2}{|c|}{ SM:115 } & \multicolumn{2}{|c|}{ SM:114 } \\
\hline & MNI & $\%$ & MNI & $\%$ & MNI & $\%$ & MNI & $\%$ & MNI & $\%$ & MNI & $\%$ & MNI & $\%$ & MNI & $\%$ \\
\hline Anadara granosa & 687 & 39.60 & 2382 & 63.69 & 혬L & 29.19 & 974 & 88.87 & 135 & 84.91 & 437 & 97.76 & 1472 & 95.52 & 467 & 93.96 \\
\hline Marcia hiantina & 2 & 0.12 & 1037 & 27.73 & 478 & 39.08 & 38 & 3.47 & & - & 1 & 0.22 & 20 & 1.30 & 8 & 1.61 \\
\hline Saccostrea cucullata & 961 & 55.39 & 224 & 5.99 & 367 & 30.01 & 61 & 5.57 & 22 & 13.84 & 4 & 0.89 & 31 & 2.01 & 15 & 3.02 \\
\hline Polymesdoa erosa & 2 & 0.12 & 2 & 0.05 & - & - & 2 & 0.18 & - & - & 1 & 0.22 & 1 & 0.06 & - & 0.00 \\
\hline Nerita lineata & 58 & 3.34 & 84 & 2.25 & 18 & 1.47 & 12 & 1.09 & 2 & 1.26 & - & - & 5 & 0.32 & 1 & 0.20 \\
\hline Volema cochlidium & 20 & 1.15 & 2 & 0.05 & 3 & 0.25 & 3 & 0.27 & - & - & 1 & 0.22 & 4 & 0.26 & 5 & 1.01 \\
\hline Telescopium telescopium & 5 & 0.29 & - & - & - & - & 6 & 0.55 & - & - & - & - & 4 & 0.26 & - & - \\
\hline Other & - & - & 9 & 0.24 & - & - & - & - & - & - & 3 & 0.67 & 4 & 0.26 & 1 & 0.20 \\
\hline Total (MNI) & 1735 & 100 & 3740 & 100 & 1223 & 100 & 1096 & 100 & 159 & 100 & 447 & 100 & 1541 & 100 & 497 & 100 \\
\hline
\end{tabular}

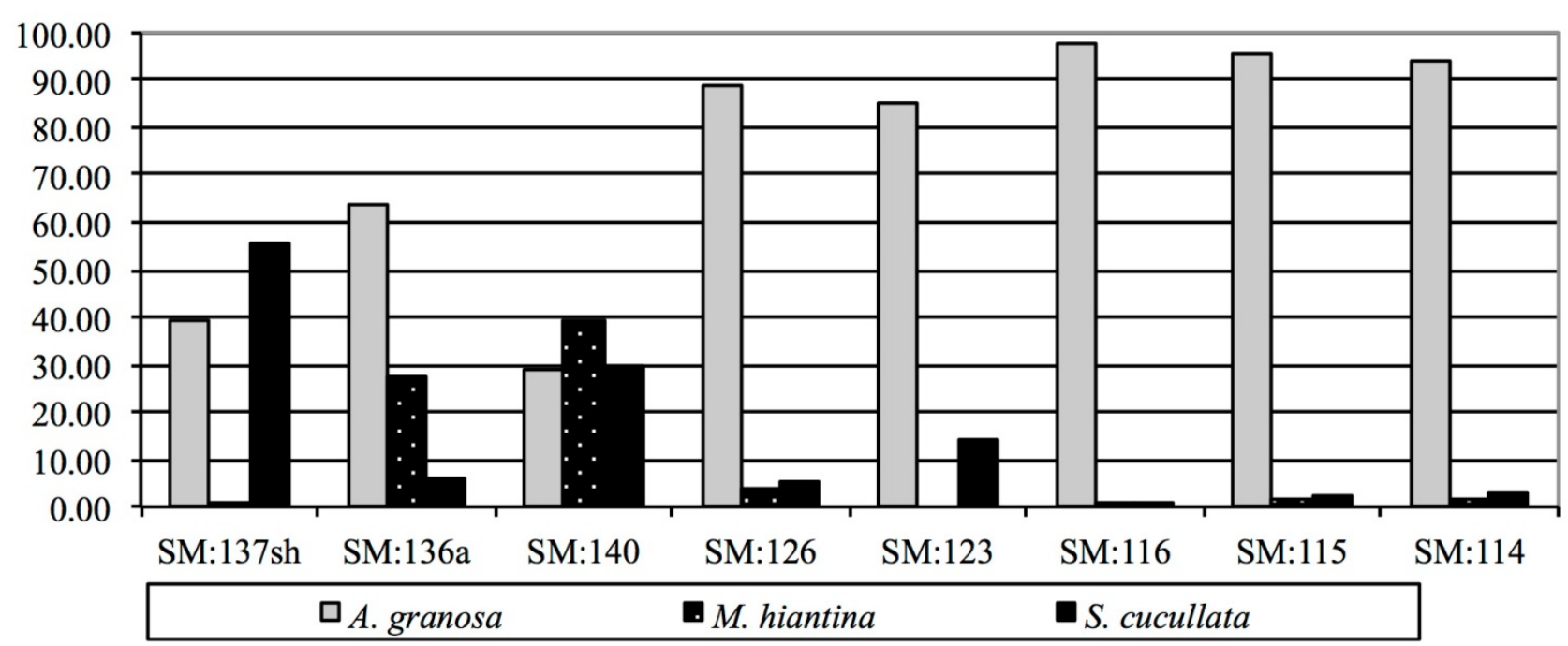

Figure 10. Dominant shellfish species by MNI for Bweening sites. 
Based on this observation, it is plausible that a relationship exists between the variety of species present in the Rhum Point shell matrix features and the greater ecological diversity within the adjacent estuary; that is, estuarine mudflats, mangroves and rocky headlands. This implies that access to a broader resource base was an influential factor in the transformation of incipient and intermediate shell mounds to larger, classic shell mound sites at Bweening. However, elsewhere at Bweening incipient and intermediate mounds appear to be more closely oriented around $A$. granosa collection events. The shell matrix features at Rhum Point West and those further south near Bweening Point contain very low proportions of species other than $A$. granosa $(>95 \%$ by MNI) suggesting that access to this species in these areas was a key motive for their initial development. While the total volume of deposits is on the whole less than those at Rhum Point, this further illustrates an important point that has emerged about the production strategies associated with shell mound formation at Weipa being intensively tied to specific niche resources (Morrison 2003, 2013). That is, shell mound development at Bweening was not reliant upon a broad resource base but that shell matrix features were primarily associated with activities focussed upon shellfish collection rather than use of other types of resources. Furthermore, at Bweening at least, A. granosa availability appears to have driven the establishment of new incipient mounds, while other species were a secondary or supplementary resource important to the development of more substantial shell mound sites.

The low proportions of non-molluscan materials found in mound sites also support the view that the production strategies associated with mound development were heavily oriented towards estuarine ecosystems. Very little other non-molluscan faunal materials were recovered from the Bweening sites. Four small fragments of mud crab claw (S. serrata) were identified across all test pits excavated on SM:137 and a single fragment of crab claw was recovered in the SM:115 spoil heap work. No other non-molluscan faunal materials were identified. Importantly, systematic investigation of $2 \mathrm{~mm}$ residues from two units of SM136a clearly indicates that proportions of diagnostic non-molluscan fauna do not increase when smaller sieve residues are investigated.

Overall only 19 stone artefacts were recovered at Bweening and all but two of these were found during the excavations (Table 24). Quartz was the most frequently encountered raw material type $(n=14)$ with silcrete $(n=2)$ and mudstone $(n=1)$ less common. Ten of the items were flakes, with nine of these made on quartz and one on mudstone. Mean flake length was $15 \mathrm{~mm}$ and width was $9.7 \mathrm{~mm}$. Five unmodified blocks were recovered, two of which were quartz and two were silcrete. Two small angular fragments of quartz were identified and it is likely these are simply stone artefact debitage given their small size. Two cores were recovered with one each on silcrete and quartz.

\section{Conclusions}

In terms of their size and morphology, the Bweening sites are good examples of the majority of shell matrix sites in the Albatross Bay region where $\sim 50 \%$ and $\sim 76 \%$ of recorded shell matrix sites are less than $1 \mathrm{~m}$ and $2 \mathrm{~m}$ in height respectively and $\sim 59 \%$ occur on bauxite substrates
(Morrison 2013). Without a clear understanding of formation processes for these types of sites, understanding the formation of far less commonly occurring larger sites as well as the further development of our understanding of the production strategies associated with shell mound formation, will remain difficult.

Three key conclusions can be drawn from the Bweening data. First, the ornithogenesis model (Stone 1995) can be soundly dismissed as having a role in mound formation at Bweening. No naturally occurring shell of any type occurs within or on bauxite plateau substrates (Taylor et al. 2008), except in areas where these are near to sea-level and close to present or past shorelines. All sites investigated at Bweening occur in locations where no coastal deposition is possible and therefore the shell component of shell matrix sites must be anthropogenic in origin. However, the ornithogenesis model includes the proviso that shell discarded by people can be scraped up to form incubation nests and this too is rejected here. There are clear stratigraphic and compositional continuities between all shell matrix sites investigated at Bweening. Incipient mounds can be clearly linked to intermediate sites, which themselves are the logical predecessor of classic shell mound deposits. Furthermore, these deposits are clearly artificial in relation to the surrounding substrate, a result that others have also demonstrated in the region (Bailey 1999; Bailey et al. 1994; Shiner et al. 2013). The Bweening sites are wholly cultural in origin and thus provide a useful benchmark for evaluating the influence of natural processes on other shell matrix sites in the region, where ornithogenesis or coastal processes may be a factor.

The second key result of this work is that a new developmental sequence for shell mounds can be now proposed. The first stage in mound development is the formation of incipient mounds, which in a sense are an unusually high-resolution record of individual discard events focussed around a central point in the landscape. Incipient mounds are relatively rare in the region, despite extensive surveys (Morrison 2013; Shiner and Morrison 2009), because these discrete deposits have been obscured and homogenised by subsequent discard and site development. Furthermore, these features are highly prone to destruction: via bioturbation on bauxite plateaus (Eggleton and Taylor 2008), via burial on coastal plains and sandy substrates (Morrison 2013), or simply as a result of the decomposition of marine shell in contexts where there was insufficient shell to form its own preservational matrix. These are not features that are likely to be well preserved beyond the last several centuries except in special geomorphic circumstances. However, with ongoing discard, the scatters comprising incipient mounds merge around a central point, forming low, roughly circular intermediate mounds while the 'background' scatters around these central mounds are either buried or destroyed. Finally, in preferred locales these intermediate mounds themselves grew into larger classic mounds that are better known in the extant literature and generally are the focus of most research. All phases of mound development appear to have involved a shifting focus in discard activity at the local level. At a longer time scale however this pattern of local variability is likely to result in very localised hiatuses in mound development or variations in shellfish accumulation rates. 
Table 24. Stone artefact data for Bweening sites.

\begin{tabular}{|c|c|c|c|c|c|c|c|}
\hline Locale & Site & $\begin{array}{c}\text { Raw } \\
\text { Material } \\
\end{array}$ & Artefact Type & $\begin{array}{c}\text { Cortex } \\
(\%) \\
\end{array}$ & $\begin{array}{c}\begin{array}{c}\text { Length } \\
\text { (mm) }\end{array} \\
\end{array}$ & $\begin{array}{l}\begin{array}{l}\text { Width } \\
(\mathrm{mm})\end{array} \\
\end{array}$ & $\begin{array}{c}\text { Thickness } \\
(\mathrm{mm})\end{array}$ \\
\hline \multirow{13}{*}{ 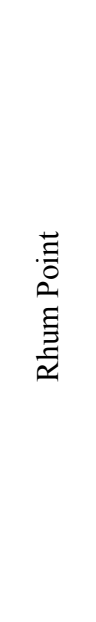 } & \multirow{5}{*}{ SM:136a } & Quartz & Flake & 0 & 11 & 7 & 3 \\
\hline & & Mudstone & Flake & 0 & 15 & 9 & 4 \\
\hline & & Quartz & Core & $50-99$ & 40 & 38 & 21 \\
\hline & & Quartz & Flake & 0 & 15 & 8 & 7 \\
\hline & & Quartz & Unmodified & $50-99$ & 24 & 14 & 13 \\
\hline & \multirow{2}{*}{ SM:140 } & Silcrete & Unmodified & $50-99$ & 88 & 69 & 46 \\
\hline & & Silcrete & Core & $50-99$ & 82 & 78 & 57 \\
\hline & \multirow{6}{*}{ SM:137sh } & Quartz & Angular Fragment & $1-49$ & 15 & 9 & 6 \\
\hline & & Silcrete & Unmodified & $50-99$ & 44 & 32 & 16 \\
\hline & & Quartz & Angular Fragment & $1-49$ & 26 & 15 & 7 \\
\hline & & Quartz & Flake & 0 & 16 & 12 & 5 \\
\hline & & Quartz & Flake & 0 & 21 & 13 & 5 \\
\hline & & Silcrete & Unmodified & $50-99$ & 4.8 & 3.7 & 2.8 \\
\hline \multirow{6}{*}{$\frac{\bar{d}}{\stackrel{D}{0}}$} & \multirow{4}{*}{ SM:115 } & Quartz & Unmodified & $50-99$ & 40 & 20 & 15 \\
\hline & & Quartz & Flake & $1-49$ & 12 & 8 & 3 \\
\hline & & Quartz & Flake & $1-49$ & 14 & 12 & 6 \\
\hline & & Quartz & Flake & $50-99$ & 26 & 16 & 9 \\
\hline & \multirow{2}{*}{ SM:114c } & Quartz & Flake & $1-49$ & 12 & 8 & 5 \\
\hline & & Quartz & Flake & 0 & 8 & 4 & 3 \\
\hline
\end{tabular}

\section{Acknowledgements}

This work was undertaken with the support of Thanakwithi traditional owners Bernice Mango, Richard Barkley, John Mango and Steven Hall and I thank them for permission to work with them on their Country. Initial work at Bweening was undertaken with the late Roger Cribb as well as the ever-vigilant rangers working at the Nanum Wungthim Land and Sea Management Centre who first noted the damage to the sites at Bweening. The work described here was funded by Comalco Aluminium Ltd (now Rio Tinto Alcan) and I thank Bella Sava and Ian Pressley for logistical and other support during the fieldwork. Ewen McPhee (James Cook University) and Richard Barkley (Senior Cultural Advisor, Napranum Aboriginal Shire Council) assisted with the excavations. Fiona Petchey and Alan Hogg (Waikato Radiocarbon Dating Laboratory) ran the radiocarbon samples and provided advice on the resulting determinations. I also thank Sally Brockwell, Sean Ulm and an anonymous referee for their constructive feedback on this paper.

\section{References}

Bailey, G.N. 1977 Shell mounds, shell middens and raised beaches in the Cape York Peninsula. Mankind 11(2):132143.

Bailey, G.N. 1993 Shell mounds in 1972 and 1992: Reflections on recent controversies at Ballina and Weipa. Australian Archaeology 37:1-17.

Bailey, G.N. 1994 The Weipa shell mounds: Natural or cultural? In M. Sullivan, S. Brockwell and A. Webb (eds), Archaeology in the North, pp.107-29. Darwin: North Australia Research Unit, Australian National University.

Bailey, G.N. 1999 Shell mounds and coastal archaeology in northern Queensland. In J. Hall and I.J. McNiven (eds), Australian Coastal Archaeology, pp.105-112. Research Papers in Archaeology and Natural History 31. Canberra: ANH Publications, Department of Archaeology and Natural History, Research School of Pacific and Asian Studies, Australian National University.
Bailey, G.N., J. Chappell and R. Cribb 1994 The origin of Anadara shell mounds at Weipa, north Queensland. Archaeology in Oceania 29(2):69-80.

Eggleton, R.A. and G. Taylor 2008 Effects of some macrobiota on the Weipa bauxite, northern Australia. Australian Journal of Earth Sciences 55:S71-S82.

Godwin, M.D. 1985 Land Units of the Weipa Region of Australia's Cape York Peninsula. Cairns, QLD: Research and Planning Branch, Queensland Parks and Wildlife Service.

Haberle, S.G. and B. David 2004 Climates of change: Human dimensions of Holocene environmental change in low latitudes of the PEPII transect. Quaternary International 118-119:165-179.

McNiven, I.J., W.R. Dickinson, B. David, M.I. Weisler, F. Von Gnielinski, M. Carter and U. Zoppi 2006 Mask Cave: Redslipped pottery and the Australian-Papuan settlement of Zenadh Kes (Torres Strait). Archaeology in Oceania 41(2):49-81

Morrison, M.J. 2002 Report to Comalco Aluminium on Damage to Cultural Heritage Sites in the Bweening Area, Weipa. Unpublished report to Comalco Aluminium Ltd.

Morrison, M.J. 2003 Old boundaries and new horizons: The Weipa shell mounds reconsidered. Archaeology in Oceania 38(1):1-8.

Morrison, M.J. 2010 The Shell Mounds of Albatross Bay: An Archaeological Investigation of Late Holocene Production Strategies near Weipa, North Eastern Australia. Unpublished $\mathrm{PhD}$ thesis, Department of Archaeology, Flinders University, Adelaide.

Morrison, M.J. 2013 Niche production strategies and shell matrix site variability at Albatross Bay, Cape York Peninsula. Archaeology in Oceania 48(2):78-91. 
Mowat, F. 1994 Size really does matter: Factors affecting shell fragmentation. In M. Sullivan, S. Brockwell and A. Webb (eds), Archaeology in the North, pp.201-212. Darwin: North Australia Research Unit, Australian National University.

Reimer, P.J., M.G.L. Baillie, E. Bard, A. Bayliss, J.W. Beck, P.G. Blackwell, C. Bronk Ramsey, C.E. Buck, G.S. Burr, R.L. Edwards, M. Friedrich, P.M. Grootes, T.P. Guilderson, I. Hajdas, T.J. Heaton, A.G. Hogg, K.A. Hughen, K.F. Kaiser, B. Kromer, F.G. McCormac, S.W. Manning, R.W. Reimer, D.A. Richards, J.R. Southon, S. Talamo, C.S.M Turney, J. van der Plicht and C.E. Weyhenmeyer 2009 IntCal09 and Marine09 radiocarbon age calibration curves, 0-50,000 years cal BP. Radiocarbon 51(4):1111-1150

Robins, R.P. 1998 Patterns in the landscape: A case study in nonsite archaeology from southwest Queensland. Memoirs of the Queensland Museum, Cultural Heritage Series $1(1): 23-56$.

Shiner, J.S., P.C. Fanning, S.J. Holdaway, F. Petchey, C. Beresford, E. Hoffman and B. Larsen 2013 Shell mounds as the basis for understanding human-environment interaction in far north Queensland, Australia. Queensland Archaeological Research 16:65-91.

Shiner, J. and M.J. Morrison 2009 The contribution of heritage surveys towards understanding the cultural landscape of the Weipa Bauxite Plateau. Australian Archaeology 68:52-55.

Specht, R.L., R.B. Salt and S.T. Reynolds 1977 Vegetation in the vicinity of Weipa, north Queensland. Proceedings of the Royal Society of Queensland 88:17-38.

Stanner, W.E.H. 1961 The Weipa shell mounds. The Etruscan 11(2):8-12.

Stone, T. 1989 Origins and environmental significance of shell and earth mounds in northern Australia. Archaeology in Oceania 24(2):59-64.
Stone, T. 1995 Shell mound formation in coastal northern Australia. Marine Geology 129:77-100.

Stuiver, M. and P.J. Reimer 1993 Extended ${ }^{14} \mathrm{C}$ database and revised CALIB radiocarbon calibration program. Radiocarbon 35:215-230.

Taylor, G., R.A. Eggleton, L.D. Foster and C.M. Morgan 2008 Landscapes and regolith of Weipa, northern Australia. Australian Journal of Earth Sciences 55:S3-S16.

Taylor, G. and T. Eggleton 2004 "Little balls": The origin of the Weipa bauxite. In I.C. Roach (ed.), Regolith 2004, pp.350254. Perth: Cooperative Research Centre for Landscape Environments and Mineral Exploration.

Ulm, S. 2002 Marine and estuarine reservoir effects in central Queensland, Australia: Determination of $\Delta \mathrm{R}$ values. Geoarchaeology 17(4):319-348.

Ulm, S. 2006 Australian marine reservoir effects: A guide to $\Delta$ R values. Australian Archaeology 63:57-60.

Ulm, S., F. Petchey, G.E. Jacobson and D. Rosendahl in press Pre-bomb marine radiocarbon reservoir variability in the eastern Gulf of Carpentaria, Queensland, Australia. Queensland Archaeological Research 17.

Valentin, H. 1959 Geomorphological reconnaissance of the northwest coast of Cape York Peninsula (northern Australia). In R.J. Russell (ed.), Second Coastal Geography Conference, pp.213-231. Washington, D.C: Coastal Studies Institute, Louisiana State University.

Wright, R.V.S. 1971 Prehistory in the Cape York Peninsula. In D.J. Mulvaney and J. Golson, (eds), Aboriginal Man and Environment in Australia, pp.133-140. Canberra: Australian National University Press. 